\title{
Effects of network structures on the tensile toughness of copper-catalyzed azide-alkyne cycloaddition (CuAAC)-based photopolymers
}

Han Byul Song ${ }^{{ }^{\dagger}}$, Nancy Sowan ${ }^{2}$, Austin Baranek ${ }^{1 \#}$, Jasmine Sinha ${ }^{l}$, Wayne D. Cook ${ }^{3}$, Christopher N. Bowman*,1,2

${ }^{1}$ Department of Chemical and Biological Engineering, University of Colorado Boulder, 596 UCB, Boulder, CO, United States

${ }^{2}$ Materials Science and Engineering Program, University of Colorado Boulder, 596 UCB, Boulder, CO, United States ${ }^{3}$ Department of Materials Science and Engineering, Monash University, Clayton, Victoria 3800, Australia

${ }^{\dagger}$ Present address: ADA Science \& Research Institute, 100 Bureau Dr, Gaithersburg, MD 20899

\# Present address: Nike inc., One Bowerman Dr, Beaverton, OR 97005

\section{Supporting Information}

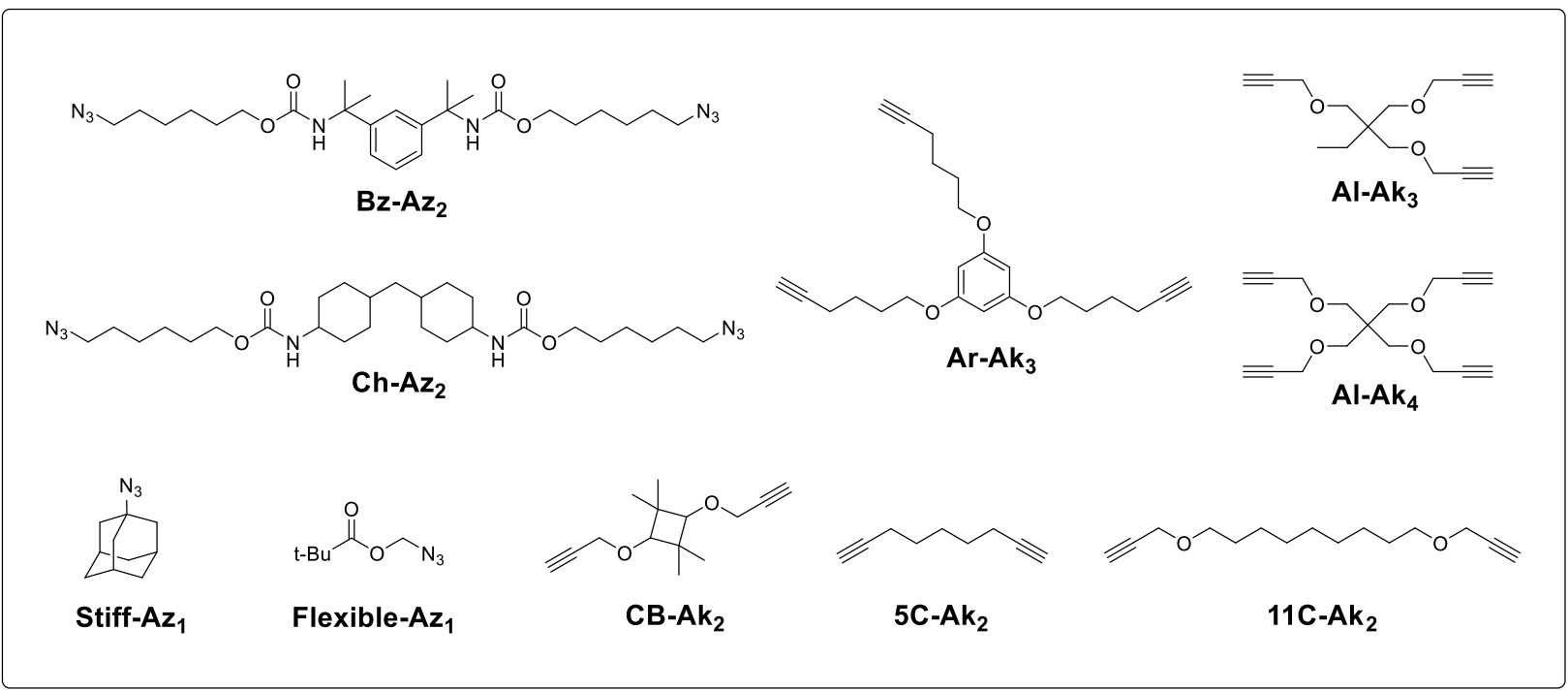

A summary of the monomers used in the study are shown above. Two azide monomers, Bz-Az 2 and $\mathrm{Ch}-\mathrm{Az}_{2}$ and four alkyne monomers, $\mathrm{Al}-\mathrm{Ak}_{3}, \mathrm{Ar}-\mathrm{Ak}_{3}, \mathrm{Al}-\mathrm{Ak} 4$, and $\mathrm{CB}-\mathrm{Ak}_{2}$, were synthesized according to previously reported procedures. ${ }^{1-3}$ The diyne monomer, $11 \mathrm{C}-\mathrm{Ak}_{2}$, was newly synthesized based on the methods employed with the other alkyne monomers. Two monofunctional azide monomers, Stiff- $\mathrm{Az}_{1}$ and Flexible-Az1, and one alkyne monomer, $5 \mathrm{C}-\mathrm{Ak}_{2}$, were commercially purchased and used without further purification. All crosslinked networks were 
composed of a stoichiometric ratio of azide groups and alkyne groups. For each polymer network, formulation is given by the acronym of $\mathrm{X}-\mathrm{Az} \mathrm{y}+\mathrm{X}-\mathrm{Aky}$, where $\mathrm{X}=$ the backbone structure in the multi-functional monomer or the side group in the mono-functional monomer, $\mathrm{Az}=$ azide monomer, $\mathrm{Ak}=$ alkyne monomer, and $\mathrm{y}=$ monomer functionality. When more than one azide or alkyne monomers were used to formulate the networks, acronyms of $\mathrm{X}_{1}-\mathrm{Az}_{\mathrm{y} 1}+\mathrm{X}_{2}-\mathrm{Az}_{\mathrm{y} 2}+\mathrm{X}_{3-}$ $A k_{y 3}$ for the use of two azide monomers and $\mathrm{X}_{1}-\mathrm{Az}_{\mathrm{y} 1}+\mathrm{X}_{2}-\mathrm{Ak}_{\mathrm{y} 2}+\mathrm{X}_{3}-\mathrm{Ak}_{\mathrm{y} 3}$ for the use of two alkyne monomers were utilized to describe the networks.

\section{Monomer Synthesis}

Synthesis of 1-(prop-2-yn-1-yloxy)-2,2-bis((prop-2-yn-1-yloxy)methyl)butane (Al-Ak $\left.k_{3}\right)^{1,2}$

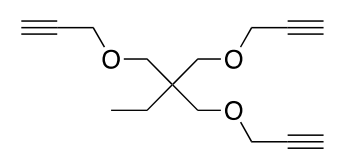

A round bottom flask equipped with a magnetic stir bar was charged with 1,1,1tris(hydroxymethyl)propane (1.97 g, $14.7 \mathrm{mmol}, 1.00$ equiv) and dissolved in DMSO (15.0 mL, $0.98 \mathrm{M})$. To the reaction flask, $10.0 \mathrm{~mL}$ of a $40 \mathrm{w} / \mathrm{w} \%$ solution of $\mathrm{NaOH}$ in water was added and stirred for 1 hour at ambient temperature. Propargyl bromide $(9.00 \mathrm{~mL}$ of an $80 \%$ solution in toluene; $9.62 \mathrm{~g}, 80.8 \mathrm{mmol}, 5.50$ equiv) was slowly added dropwise, and the reaction was stirred for 3 days at ambient temperature. After this period, the reaction was extracted with ethyl acetate followed by washing with excess water. The combined organic phase was dried over $\mathrm{Na}_{2} \mathrm{SO}_{4}$, filtered, and concentrated. The crude product was then purified using column chromatography (1:9 EtOAc:Hex) to obtain a colorless oil. (2.63g, $72 \%$ yield based on the 1,1,1tris(hydroxymethyl)propane) 

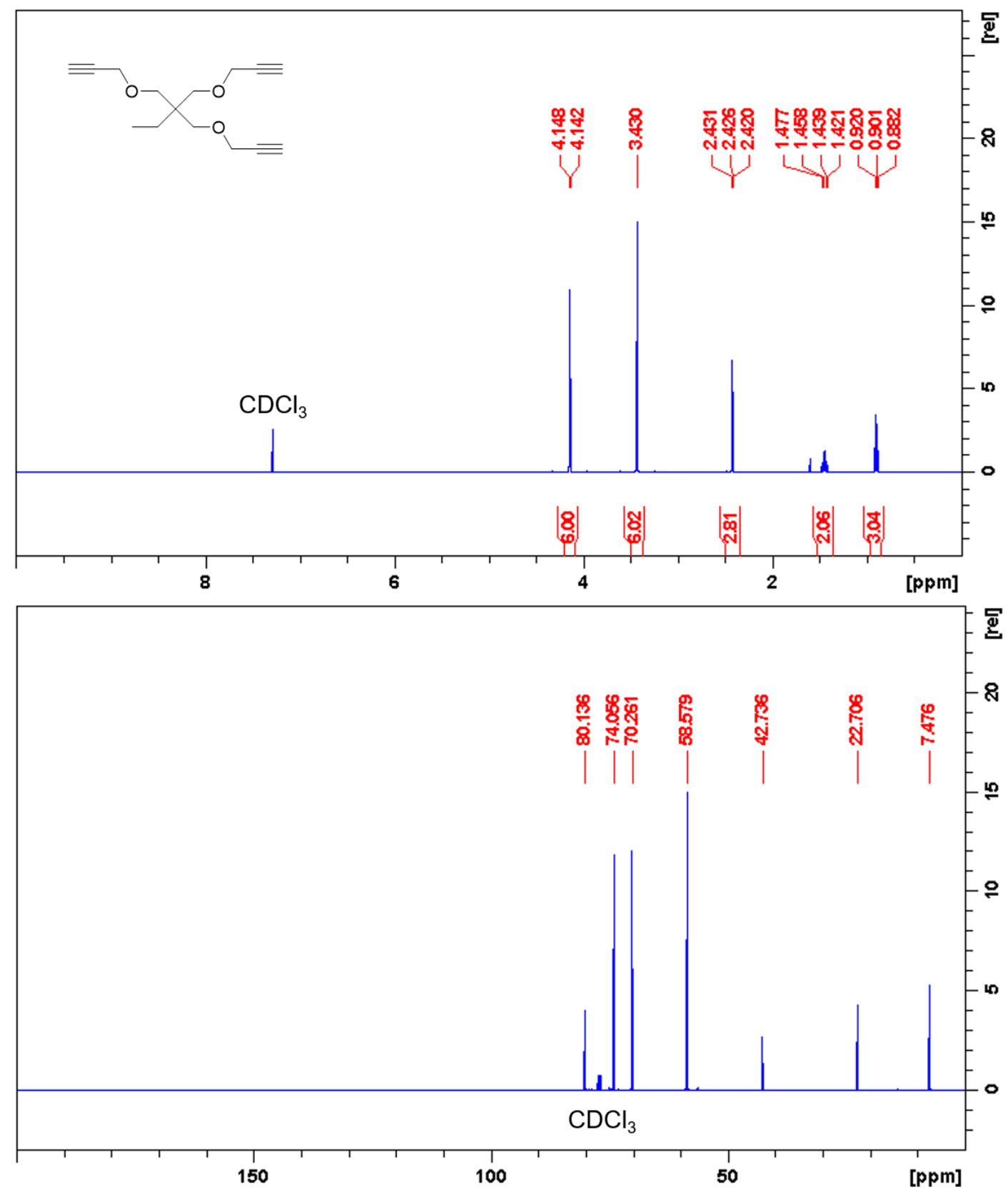

Figure S1. ${ }^{1} \mathrm{H}-\mathrm{NMR}$ and ${ }^{13} \mathrm{C}-\mathrm{NMR}$ spectra of 1-(prop-2-yn-1-yloxy)-2,2-bis((prop-2-yn-1yloxy)methyl)butane $\left(\mathrm{Al}^{\left.-\mathrm{Ak}_{3}\right) .}{ }^{1} \mathrm{H} \mathrm{NMR}\left(\mathrm{CDCl}_{3}\right) \delta: 0.90\left(3 \mathrm{H}, \mathrm{t}, \mathrm{J}=7.48 \mathrm{~Hz}, \mathrm{CH}_{3}\right), 1.45(2 \mathrm{H}, \mathrm{q}, \mathrm{J}=7.58\right.$ $\left.\mathrm{Hz}, \mathrm{CH}_{2}-\mathrm{CH}_{3}\right), 2.42\left(3 \mathrm{H}, \mathrm{t}, \mathrm{J}=2.39 \mathrm{~Hz}\right.$, alkyne-H), $3.43\left(6 \mathrm{H}, \mathrm{s}, \mathrm{CH}_{2}\right), 4.14\left(6 \mathrm{H}, \mathrm{d}, \mathrm{J}=2.63 \mathrm{~Hz}, \mathrm{CH}_{2}-\right.$ alkyne); ${ }^{13} \mathrm{C}$ NMR $\left(\mathrm{CDCl}_{3}\right) \delta: 7.48\left(1 \mathrm{C}, \mathrm{CH}_{3}\right), 22.71\left(1 \mathrm{C}, \mathrm{CH}_{2}\right), 42.74(1 \mathrm{C}, \mathrm{C}$, core $), 58.58\left(3 \mathrm{C}, \mathrm{CH}_{2}-\right.$ alkyne), 70.26 (3C, $\left.\mathrm{CH}_{2}\right), 74.06$ (3C, $\mathrm{CH}$, alkyne), 80.14 (3C, $\mathrm{C}$, alkyne). 
Synthesis of 3-(3-(prop-2-yn-1-yloxy)-2,2-bis((prop-2-yn-1-yloxy)methyl)propoxy)prop-1-yne $\left(A l-A k_{4}\right):^{3}$

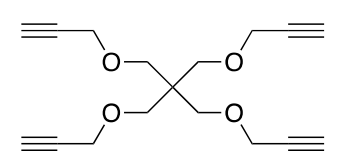

A round bottom flask equipped with a magnetic stir bar was charged with pentaerythritol $(10 \mathrm{~g}$, $73.5 \mathrm{mmol}, 1.00$ equiv) and dissolved in THF ( $250 \mathrm{~mL}, 0.29 \mathrm{M})$. To the reaction flask, $\mathrm{KOH}$ (57 g, 1.05 mol, 14.3 equiv) and TBAI ( $0.35 \mathrm{~g}, 0.95 \mathrm{mmol}, 0.013$ equiv) were added, and the flask was equipped with a reflux condenser. Propargyl bromide $(65.5 \mathrm{~mL}$ of an $80 \%$ solution in toluene; $70.0 \mathrm{~g}, 0.59 \mathrm{~mol}, 8.00$ equiv) was slowly added dropwise, and the reaction was stirred for 3.5 hours at $70{ }^{\circ} \mathrm{C}$. After this period, the reaction was extracted with ethyl acetate followed by washing with $1 \mathrm{M} \mathrm{NaOH}$ and excess water. The combined organic phase was dried over $\mathrm{Na}_{2} \mathrm{SO}_{4}$, filtered, and concentrated. The crude product was recrystallized in ethyl acetate at $0{ }^{\circ} \mathrm{C}$ to obtain a yellow solid. (5.72g, 27\% yield based on the pentaerythritol) 

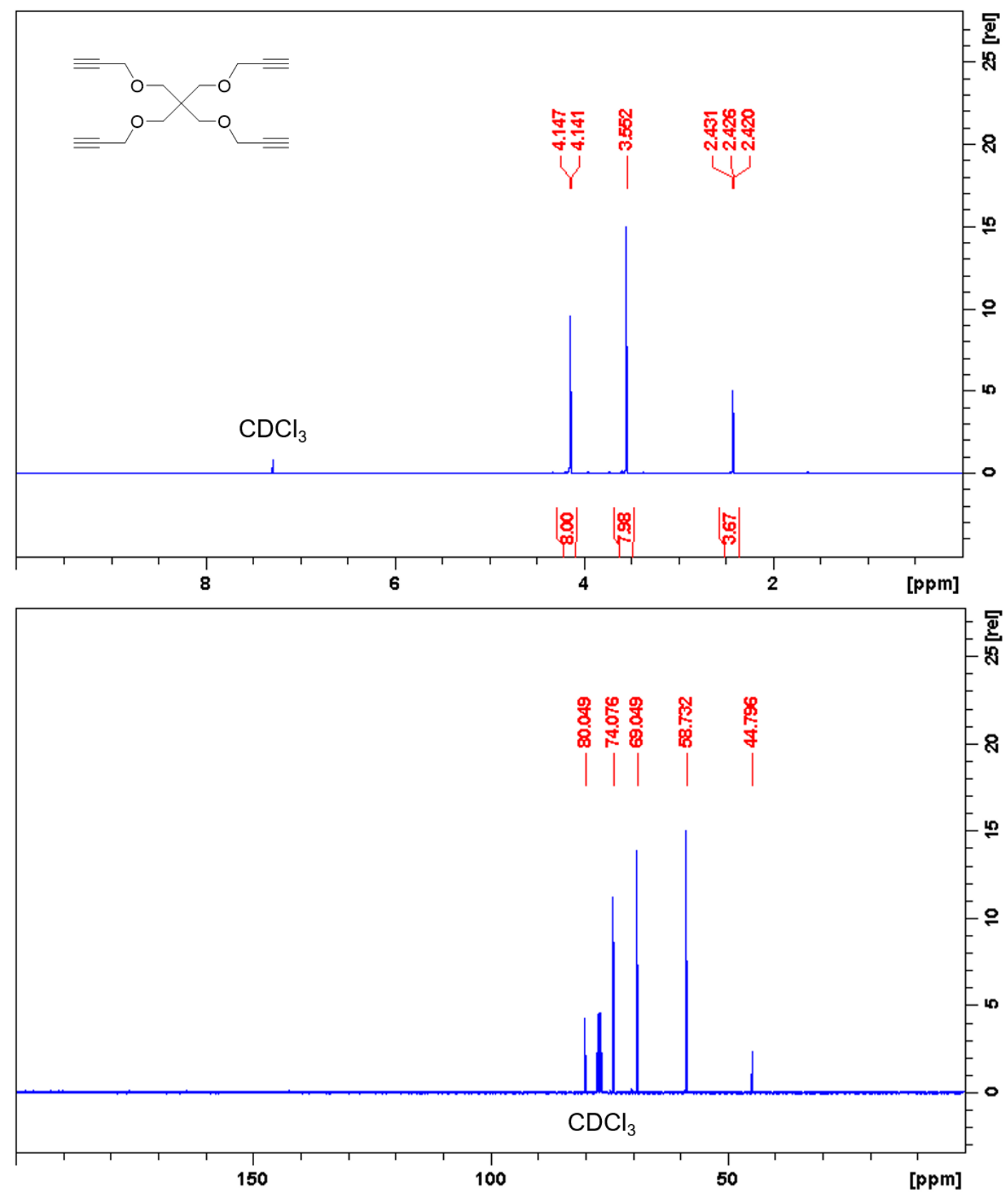

Figure S2. ${ }^{1} \mathrm{H}-\mathrm{NMR}$ and ${ }^{13} \mathrm{C}-\mathrm{NMR}$ spectra of 3-(3-(prop-2-yn-1-yloxy)-2,2-bis((prop-2-yn-1yloxy)methyl)propoxy)prop-1-yne (Al-Ak 4$) .{ }^{1} \mathrm{H} \mathrm{NMR}\left(\mathrm{CDCl}_{3}\right) \delta: 2.42(4 \mathrm{H}, \mathrm{t}, \mathrm{J}=2.38 \mathrm{~Hz}, \mathrm{CH}$, alkyne), $3.55\left(8 \mathrm{H}, \mathrm{s}, \mathrm{CH}_{2}\right), 4.15\left(8 \mathrm{H}, \mathrm{d}, \mathrm{J}=2.38 \mathrm{~Hz}, \mathrm{CH}_{2}\right.$-alkyne $) ;{ }^{13} \mathrm{C} \mathrm{NMR}\left(\mathrm{CDCl}_{3}\right) \delta: 44.80(1 \mathrm{C}, \mathrm{C}$, core $), 58.73$ (4C, $\mathrm{CH}_{2}$-alkyne), 69.05 (4C, $\mathrm{CH}_{2}$ ), 74.08 (4C, $\mathrm{CH}$, alkyne), 80.05 (4C, $\mathrm{C}$, alkyne). 
Synthesis of 1,3,5-tris(hex-5-yn-1-yloxy)benzene $\left(A r-A k_{3}\right):^{3}$

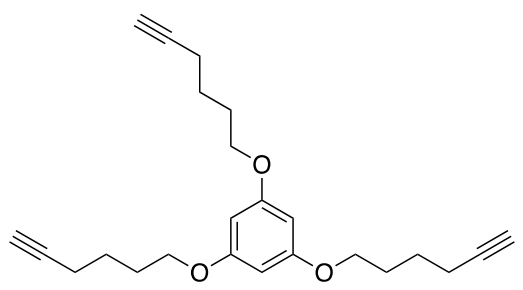

A round bottom flask equipped with a magnetic stir bar was charged with phloroglucinol (1.0 g, $7.93 \mathrm{mmol}, 1.00$ equiv) and dissolved in DMF (50 mL, $0.16 \mathrm{M})$. To the reaction flask, $\mathrm{K}_{2} \mathrm{CO}_{3}$ ( $6.58 \mathrm{~g}, 47.6 \mathrm{mmol}, 6.00$ equiv) was added, and the flask was equipped with a reflux condenser. 6-Chloro-1-hexyne $(6.73 \mathrm{~mL}, 55.50 \mathrm{~mol}, 7.00$ equiv) was slowly added dropwise, and the reaction was stirred for 24 hours at $100{ }^{\circ} \mathrm{C}$. After this period, the reaction was extracted with ethyl acetate followed by washing with $1 \mathrm{M} \mathrm{NaOH}$ and excess water. The combined organic phase was dried over $\mathrm{Na}_{2} \mathrm{SO}_{4}$, filtered, and concentrated. The crude product was then purified using column chromatography (1:9 EtOAc:Hex) to obtain a white solid. $(1.34 \mathrm{~g}, 46 \%$ yield based on the phloroglucinol) 

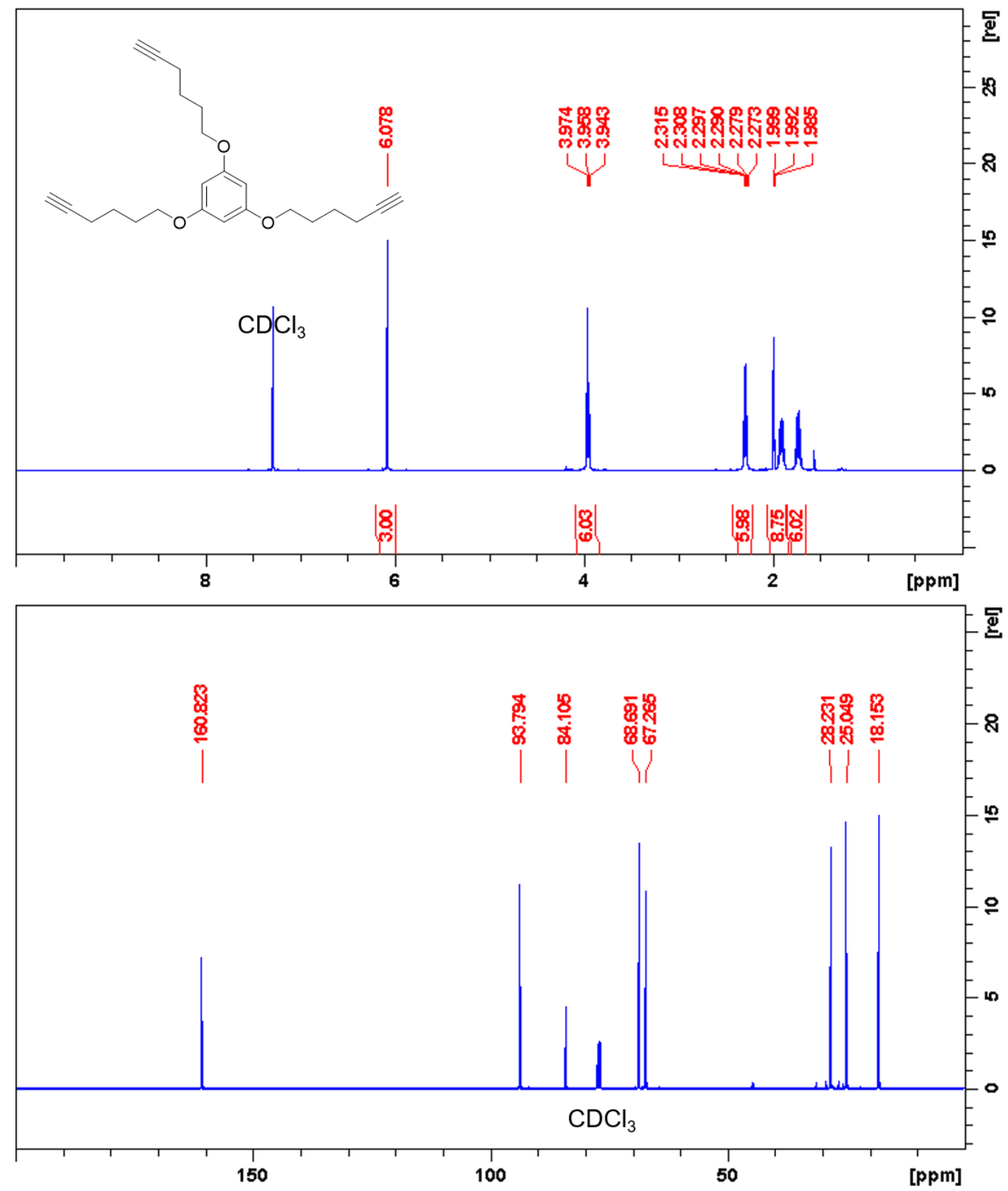

Figure S3. ${ }^{1} \mathrm{H}-\mathrm{NMR}$ and ${ }^{13} \mathrm{C}-\mathrm{NMR}$ spectra of 1,3,5-tris(hex-5-yn-1-yloxy)benzene $\left(\mathrm{Ar}^{\left.-\mathrm{Ak}_{3}\right) .}{ }^{1} \mathrm{H}\right.$ NMR

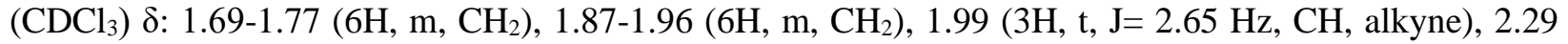
$\left(6 \mathrm{H}, \mathrm{td}, \mathrm{J}=7.16,2.67 \mathrm{~Hz}, \mathrm{CH}_{2}\right.$-alkyne), $3.95\left(6 \mathrm{H}, \mathrm{t}, \mathrm{J}=6.29 \mathrm{~Hz}, \mathrm{CH}_{2}-\mathrm{O}\right), 6.08\left(3 \mathrm{H}, \mathrm{s}, \mathrm{CH}\right.$, aromatic); ${ }^{13} \mathrm{C}$ NMR $\left(\mathrm{CDCl}_{3}\right) \delta$ : 18.15 (3C, $\mathrm{CH}_{2}$-alkyne), 25.05, $28.23\left(6 \mathrm{C}, \mathrm{CH}_{2}-\mathrm{CH}_{2}\right), 67.27\left(3 \mathrm{C}, \mathrm{CH}_{2}-\mathrm{O}\right), 68.69$ (3C, $\mathrm{CH}$, alkyne), 84.10 (3C, C, alkyne), 93.80 (3C, $\mathrm{CH}$, aromatic), 160.82 (3C, C, aromatic). 
Synthesis of 1,1,3,3-tetramethyl-2,4-bis(prop-2-yn-1-yloxy)cyclobutene (CB-Ak $):^{3}$

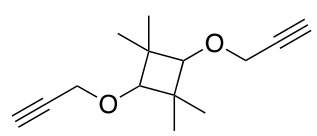

A round bottom flask equipped with a magnetic stir bar was charged with 2,2,4,4-tetramethyl1,3-cyclobutanediol (1.00 g, $6.93 \mathrm{mmol}, 1.00$ equiv) and dissolved in THF (20.0 mL, $0.35 \mathrm{M})$. To the reaction flask, $\mathrm{KOH}(2.65 \mathrm{~g}, 47.15 \mathrm{mmol}, 6.80$ equiv) and TBAI (17.5 mg, $0.048 \mathrm{mmol}$, 0.007 equiv) were added, and the flask was equipped with a reflux condenser. Propargyl bromide (3.00 mL of an $80 \%$ solution in toluene; $3.20 \mathrm{~g}, 26.9 \mathrm{mmol}, 3.89$ equiv) was slowly added dropwise, and the reaction was stirred for 3.5 hours at $70{ }^{\circ} \mathrm{C}$. After this period, the reaction was extracted with ethyl acetate followed by washing with $1 \mathrm{M} \mathrm{NaOH}$ and excess water. The combined organic phase was dried over $\mathrm{Na}_{2} \mathrm{SO}_{4}$, filtered, and concentrated. The crude product was then passed through a silica plug with 1:9 EtOAc:Hex solvent system and recrystallized from methanol to obtain a white solid. $(1.10 \mathrm{~g}, 72 \%$ yield based on the 2,2,4,4-tetramethyl-1,3cyclobutanediol) 

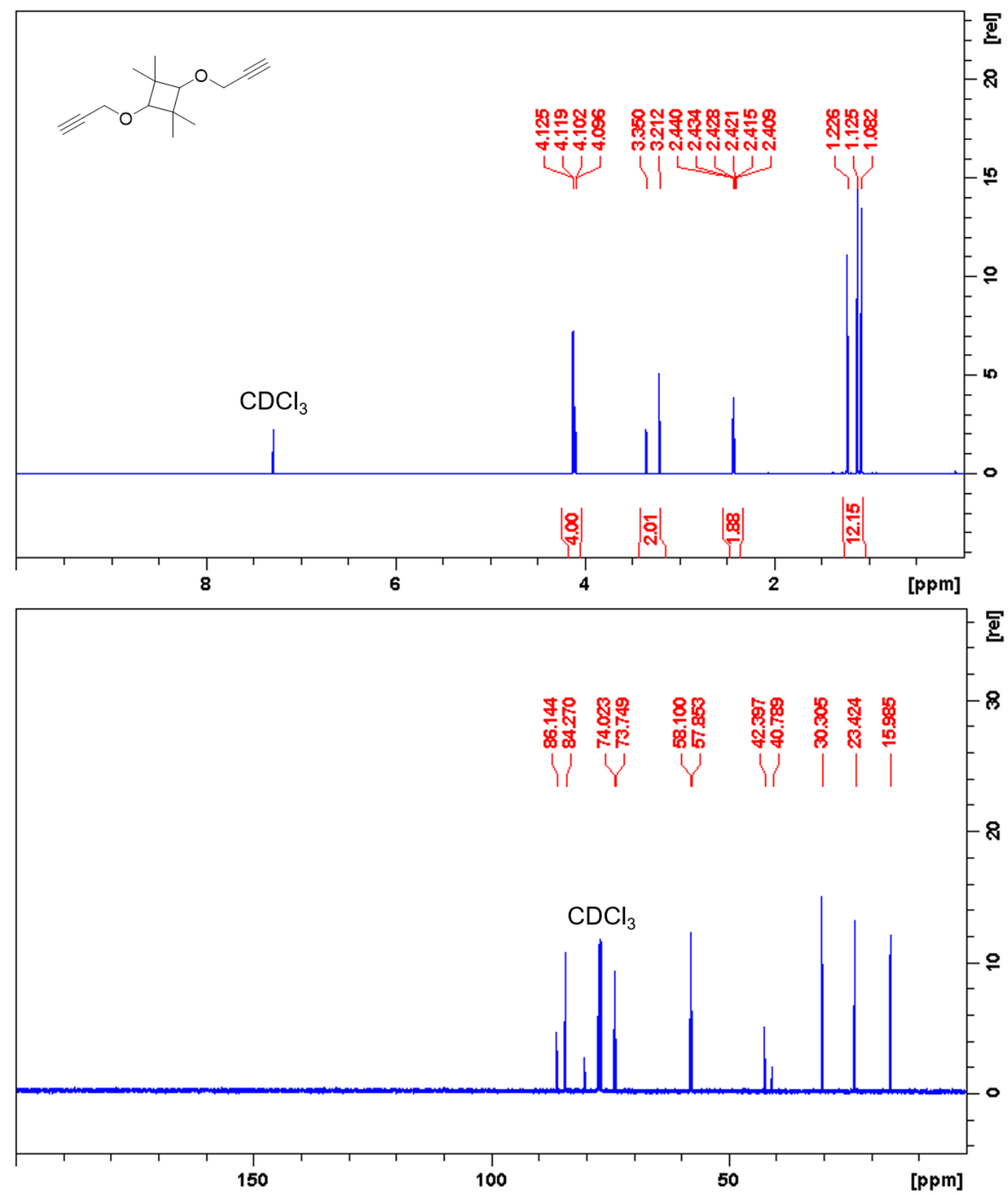

Figure S4. ${ }^{1} \mathrm{H}-\mathrm{NMR}$ and ${ }^{13} \mathrm{C}-\mathrm{NMR}$ spectra of 1,1,3,3-tetramethyl-2,4-bis(prop-2-yn-1-yloxy)cyclobutene $\left(\mathrm{CB}-\mathrm{Ak}_{2}\right) .{ }^{1} \mathrm{H}$ NMR $\left(\mathrm{CDCl}_{3}\right) \delta: 1.08,1.12,1.23\left(12 \mathrm{H}, \mathrm{s}, \mathrm{CH}_{3}\right), 2.42,2.44$ [Mixture of isomers] $(2 \mathrm{H}, \mathrm{t}, \mathrm{J}=$ 2.42, alkyne), 3.21, 3.35 [Mixture of isomers] (2H, s, C-O), 4.10, 4.12 [Mixture of isomers] (4H, d, J= $2.35 \mathrm{~Hz}, \mathrm{CH}_{2}$-alkyne); ${ }^{13} \mathrm{C} \mathrm{NMR}\left(\mathrm{CDCl}_{3}\right) \delta$ : 15.99, 23.42 (4C, $\mathrm{CH}_{3}$-cyclobutane), 30.31 (2C, $\mathrm{C}$, cyclobutane), 40.79, 42.40 [Mixture of isomers] (2C, $\mathrm{CH}$, alkyne), 57.85, 58.10 [Mixture of isomers] (2C, $\mathrm{CH}_{2}$-alkyne), 73.75, 74.02 [Mixture of isomers] (2C, C, alkyne), 84.27, 86.14 [Mixture of isomers] (2C, C-O, cyclobutane). 
Synthesis of 1,9-bis(prop-2-yn-1-yloxy)nonane (11C-Ak2):

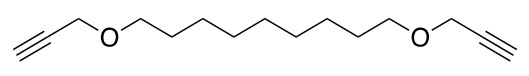

A round bottom flask equipped with a magnetic stir bar was charged with 1,9-nonanediol (5.00 g, $31.2 \mathrm{mmol}, 1.00$ equiv) and dissolved in DMSO (40.0 mL, $0.78 \mathrm{M})$. To the reaction flask, 20.0 $\mathrm{mL}$ of a $40 \mathrm{w} / \mathrm{w} \%$ solution of $\mathrm{NaOH}$ in water was added and stirred for 1 hour at ambient temperature. Propargyl bromide $(12.00 \mathrm{~mL}$ of an $80 \%$ solution in toluene; $12.8 \mathrm{~g}, 108 \mathrm{mmol}$, 3.45 equiv) was then slowly added dropwise, and the reaction was stirred for 1 day at ambient temperature. After this period, the reaction was extracted with ethyl acetate followed by washing with excess water. The combined organic phase was dried over $\mathrm{Na}_{2} \mathrm{SO}_{4}$, filtered, and concentrated. The crude product was then purified using column chromatography $(0: 10$ EtOAc:Hex) to obtain a colorless oil. (2.92g, $40 \%$ yield based on the 1,9-nonanediol) 

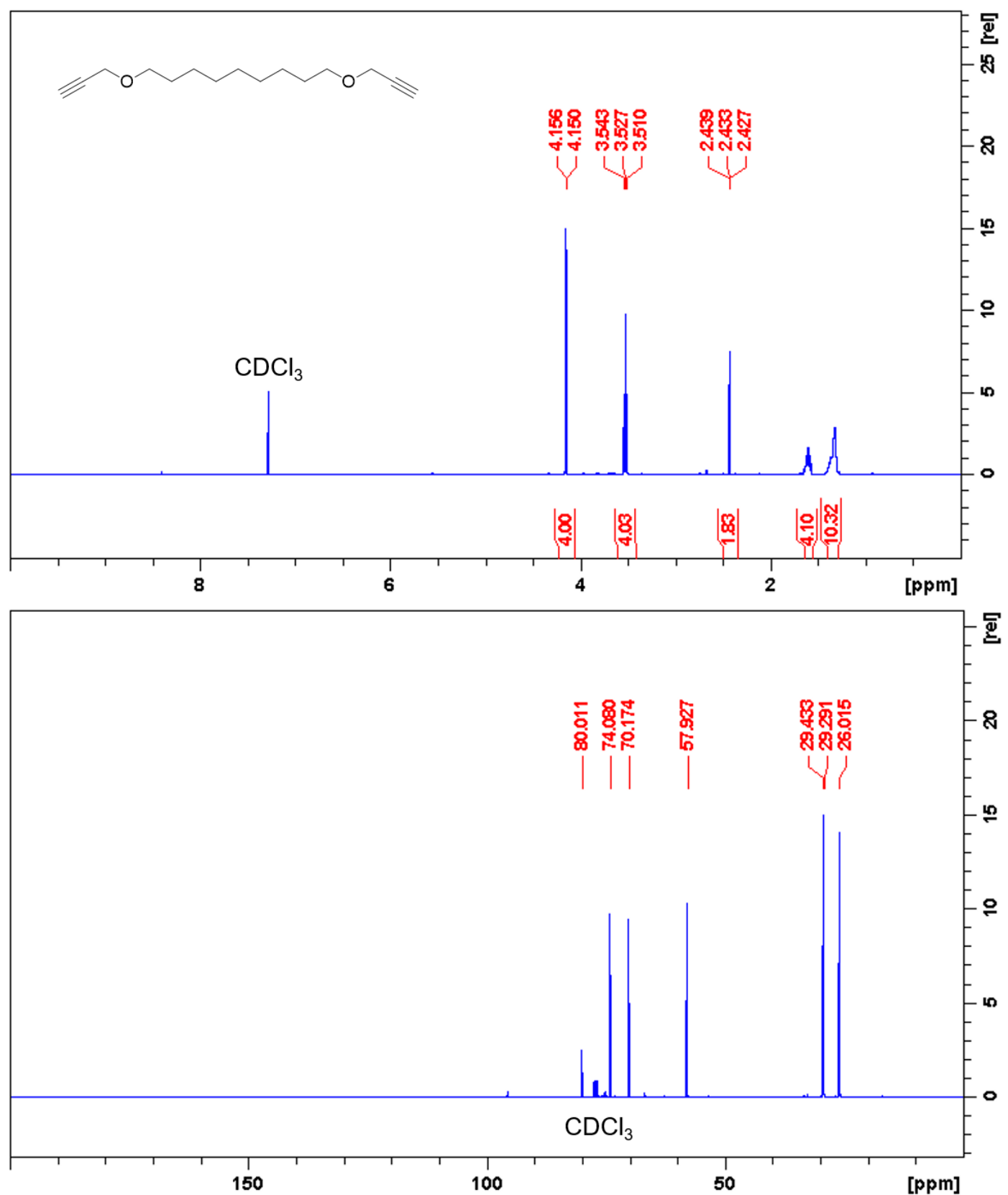

Figure S5. ${ }^{1} \mathrm{H}-\mathrm{NMR}$ and ${ }^{13} \mathrm{C}-\mathrm{NMR}$ spectra of 1,9-bis(prop-2-yn-1-yloxy)nonane (11C-Ak 2 ). ${ }^{1} \mathrm{H}$ NMR $\left(\mathrm{CDCl}_{3}\right) \delta: 1.28-1.42\left(10 \mathrm{H}, \mathrm{m}, \mathrm{CH}_{2}\right), 1.56-1.65\left(4 \mathrm{H}, \mathrm{m}, \mathrm{CH}_{2}\right), 2.43(2 \mathrm{H}, \mathrm{t}, \mathrm{J}=2.38 \mathrm{~Hz}$, alkyne-H), 3.53 $\left(4 \mathrm{H}, \mathrm{t}, \mathrm{J}=6.74 \mathrm{~Hz}, \mathrm{CH}_{2}-\mathrm{O}\right), 4.15\left(4 \mathrm{H}, \mathrm{d}, \mathrm{J}=2.35 \mathrm{~Hz}, \mathrm{CH}_{2}\right.$-alkyne); ${ }^{13} \mathrm{C} \mathrm{NMR}\left(\mathrm{CDCl}_{3}\right) \delta: 26.02,29.29$, 29.43 (7C, $\mathrm{CH}_{2}$ ), 57.93 (2C, $\mathrm{CH}_{2}$-alkyne), 70.17 (2C, $\left.\mathrm{CH}_{2}-\mathrm{O}\right), 74.08$ (2C, $\mathrm{CH}$, alkyne), 80.01 (2C, $\mathrm{C}$, alkyne). 
Synthesis of bis(6-azidohexyl) (1,3-phenylenebis(propane-2,2-diyl))dicarbamate $\left(B z-A z_{2}\right):^{2}$

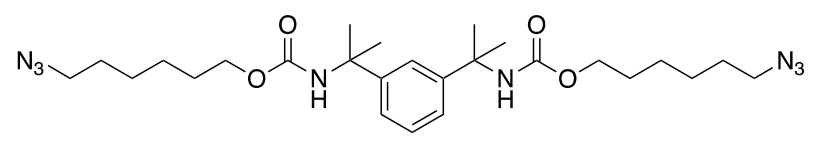

A round bottom flask equipped with a magnetic stir bar and purged with argon was charged with 1,3-bis(2-isocyanatopropan-2-yl)benzene $(1.00 \mathrm{~g}, 4.09 \mathrm{mmol}, 1.00$ equiv) and dibutyltin dilaurate (3 drops, 0.012 equiv) and dissolved in anhydrous THF (3.00 mL, $1.36 \mathrm{M})$. The reaction flask was then cooled to $0{ }^{\circ} \mathrm{C}$ by placing in an ice bath. 6-Chloro-1-hexanol $(1.12 \mathrm{~mL}$, $8.38 \mathrm{mmol}, 2.05$ equiv) was added dropwise to the reaction. The reaction was removed from the ice bath, allowed to equilibrate to room temperature, and reacted for 12 hours. Following completion of the reaction, the mixture was diluted with excess THF, passed through a silica plug to remove the tin catalyst, and dried in vacuo as a colorless oil. The dried product dicarbamate chloride intermediate $(2.00 \mathrm{~g}, 3.86 \mathrm{mmol}, 1.00$ equiv) was transferred to a round bottom flask equipped with a magnetic stir bar and dissolved in DMF (30.0 mL, 0.13 M). Sodium azide ( $1.00 \mathrm{~g}, 15.4 \mathrm{mmol}, 4.00$ equiv) was then added, and the flask was equipped with a reflux condenser and allowed to react at $80{ }^{\circ} \mathrm{C}$ for 24 hours. The reaction flask was then cooled to ambient temperature, and the product was extracted with ethyl acetate followed by washing with excess water. The combined organic phase was dried over $\mathrm{Na}_{2} \mathrm{SO}_{4}$, filtered, and concentrated. The crude product was then purified using column chromatography (2:8 EtOAc:Hex) to obtain a colorless oil. (1.98g, 91\% yield based on the 1,3-bis(2-isocyanatopropan-2-yl)benzene) 

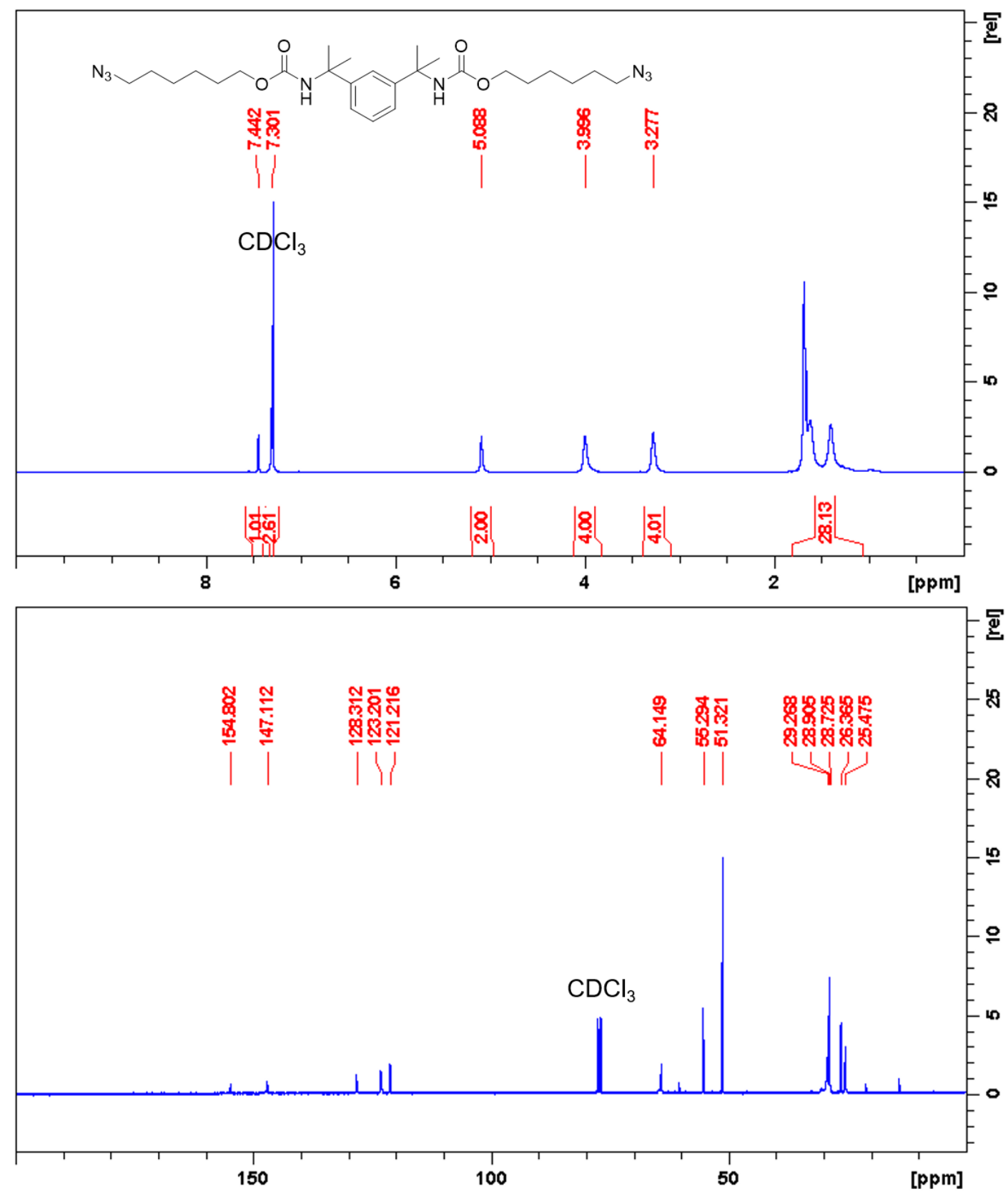

Figure S6. ${ }^{1} \mathrm{H}-\mathrm{NMR}$ and ${ }^{13} \mathrm{C}-\mathrm{NMR}$ spectra of bis(6-azidohexyl) (1,3-phenylenebis(propane-2,2diyl))dicarbamate $\left(\mathrm{Bz}_{-} \mathrm{Az}_{2}\right) .{ }^{1} \mathrm{H} \mathrm{NMR}\left(\mathrm{CDCl}_{3}\right) \delta: 1.15-1.75\left(28 \mathrm{H}, \mathrm{m}, \mathrm{CH}_{2}, \mathrm{CH}_{3}\right), 3.28\left(4 \mathrm{H}, \mathrm{s}, \mathrm{CH}_{2}-\mathrm{N}_{3}\right)$, 3.99 (4H, s, $\mathrm{CH}_{2}$-carbamate), $5.10(2 \mathrm{H}, \mathrm{s}, \mathrm{NH}$, carbamate), $7.30(3 \mathrm{H}, \mathrm{s}, \mathrm{CH}$-aromatic), $7.44(1 \mathrm{H}, \mathrm{s}, \mathrm{CH}-$ aromatic); ${ }^{13} \mathrm{C}$ NMR $\left(\mathrm{CDCl}_{3}\right) \delta: 25.48,26.37,28.91,29.27\left(8 \mathrm{C}, \mathrm{CH}_{2}\right), 28.73\left(4 \mathrm{C}, \mathrm{CH}_{3}\right), 51.32\left(2 \mathrm{C}, \mathrm{CH}_{2}-\right.$ $\mathrm{N}_{3}$ ), 55.29 (2C, C, aliphatic), 64.15 (2C, $\mathrm{CH}_{2}-\mathrm{O}$, carbamate), 121.22, 123.20, 128.31 (4C, $\mathrm{CH}$, aromatic), 147.11 (2C, C, aromatic) 154.80 (2C, C=O, carbamate). 
Synthesis of bis(6-azidohexyl) (methylenebis(cyclohexane-4,1-diyl))dicarbamate (Ch-Azz): ${ }^{2}$

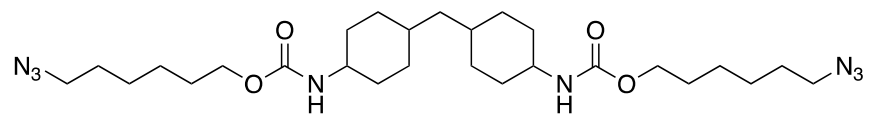

A round bottom flask equipped with a magnetic stir bar and purged with argon was charged with 4,4-methylenebis(cyclohexyl isocyanate) $(1.07 \mathrm{~g}, 4.09 \mathrm{mmol}, 1.00$ equiv) and dibutyltin dilaurate (3 drops, 0.012 equiv) and dissolved in anhydrous THF (3.00 mL, 1.36 M). The reaction flask was then cooled to $0{ }^{\circ} \mathrm{C}$ by placing in an ice bath. 6-Chloro-1-hexanol $(1.12 \mathrm{~mL}, 8.38 \mathrm{mmol}, 2.05$ equiv) was added dropwise to the reaction. The reaction was removed from the ice bath, allowed to equilibrate to room temperature, and reacted for 12 hours. Following completion of the reaction, the mixture was diluted with excess THF, passed through a silica plug to remove the tin catalyst, and dried in vасио as a colorless oil. The dried product - dicarbamate chloride intermediate ( $2.07 \mathrm{~g}, 3.86 \mathrm{mmol}, 1.00$ equiv) was transferred to a round bottom flask equipped with a magnetic stir bar and dissolved in DMF $(30.0 \mathrm{~mL}, 0.13 \mathrm{M})$. Sodium azide $(1.00 \mathrm{~g}, 15.4$ mmol, 4.00 equiv) was then added, and the flask was equipped with a reflux condenser and allowed to react at $80^{\circ} \mathrm{C}$ for 24 hours. The reaction flask was then cooled to ambient temperature, and the product was extracted with ethyl acetate followed by washing with excess water. The combined organic phase was dried over $\mathrm{Na}_{2} \mathrm{SO}_{4}$, filtered, and concentrated. The crude product was then purified using column chromatography to obtain a colorless oil. $(1.80 \mathrm{~g}, 80 \%$ yield based on the 4,4-methylenebis(cyclohexyl isocyanate)) 


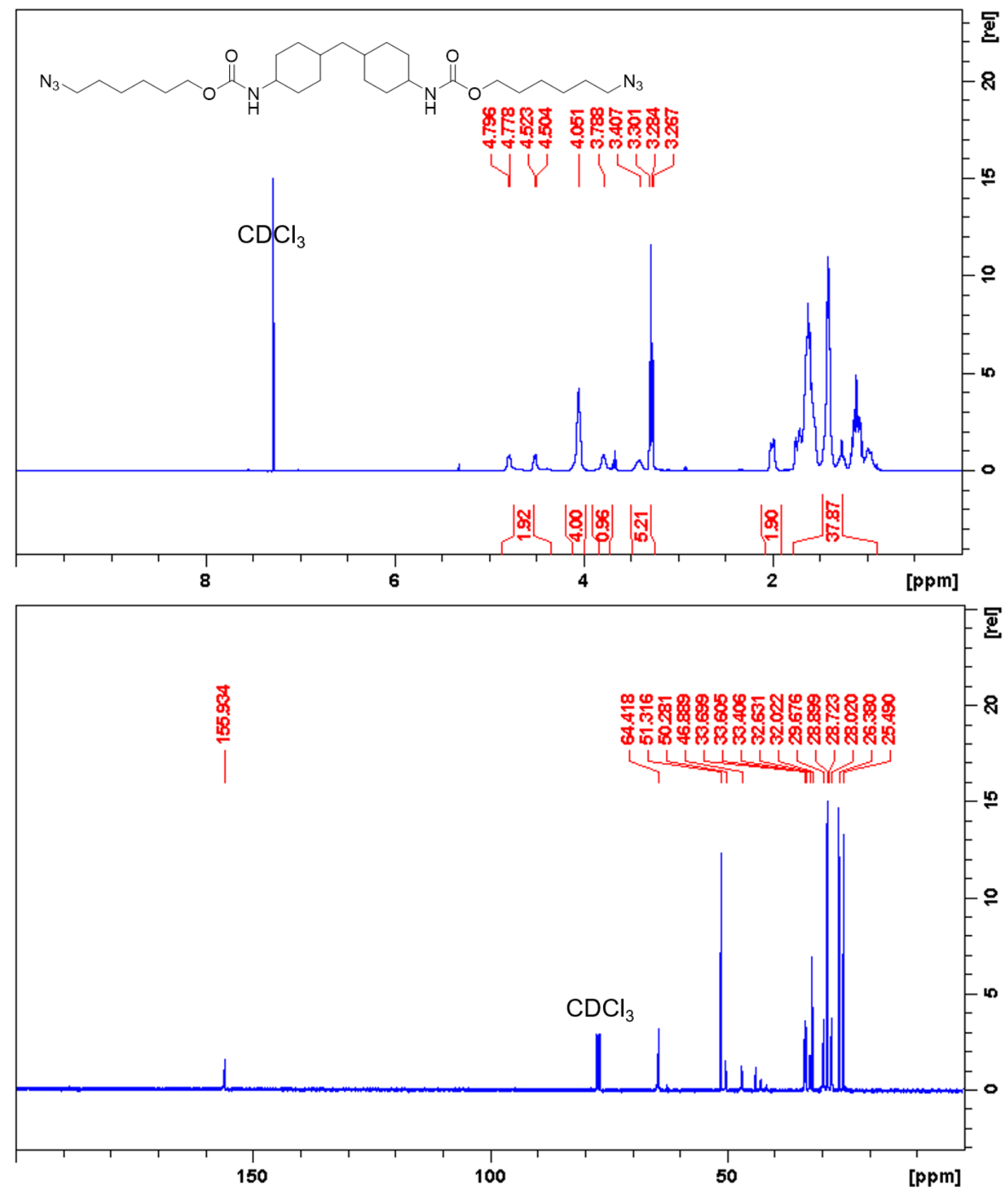

Figure S7. ${ }^{1} \mathrm{H}-\mathrm{NMR}$ and ${ }^{13} \mathrm{C}-\mathrm{NMR}$ spectra of bis(6-azidohexyl) (methylenebis(cyclohexane-4,1diyl))dicarbamate $\left(\mathrm{Ch}-\mathrm{Az}_{2}\right) .{ }^{1} \mathrm{H} \mathrm{NMR}\left(\mathrm{CDCl}_{3}\right) \delta: 0.90-2.05\left(36 \mathrm{H}, \mathrm{m}, \mathrm{CH}_{2}, \mathrm{CH}\right), 3.28(4 \mathrm{H}, \mathrm{t}, \mathrm{J}=6.88 \mathrm{~Hz}$, $\left.\mathrm{CH}_{2}-\mathrm{N}_{3}\right), 3.44,3.79$ [Mixture of isomers] (2H, s, NH, carbamate), 4.05 (4H, s, $\mathrm{CH}_{2}$-carbamate), 4.52, 4.78 [Mixture of isomers] $(2 \mathrm{H}, \mathrm{d}, \mathrm{J}=7.37, \mathrm{CH}-\mathrm{NH}) ;{ }^{13} \mathrm{C} \mathrm{NMR}\left(\mathrm{CDCl}_{3}\right) \delta$ : 25.49, 26.38, 28.02, 28.72, 28.90, 29.68, 32.02, 32.63, 33.41, 33.61, 33.70 [Mixture of isomers] (18C, $\left.\mathrm{CH}, \mathrm{CH}_{2}\right), 46.89$ (1C, cyclohex- $\mathrm{CH}_{2}$ cyclohex), $50.28\left(2 \mathrm{C}, \mathrm{CH}_{2}-\mathrm{N}_{3}\right), 51.32$ (2C, $\mathrm{CH}-\mathrm{NH}$, carbamate), 64.42 (2C, $\mathrm{CH}_{2}-\mathrm{O}$, carbamate), 155.93 $(2 \mathrm{C}, \mathrm{C}=\mathrm{O}$, carbamate) 
Preparation of $\mathrm{CuCl}_{2}[\mathrm{PMDETA}]$ complex: 1:1 molar mixture of $\mathrm{CuCl}_{2}$ and PMDETA $\left(\mathrm{N}, \mathrm{N}, \mathrm{N}^{\prime}, \mathrm{N}^{\prime}, \mathrm{N}^{\prime \prime}\right.$-pentamethyldiethylenetriamine) in acetonitrile was stirred overnight at room temperature and concentrated in vacuo to a blue-green solid.

\section{Polymer Characterization}

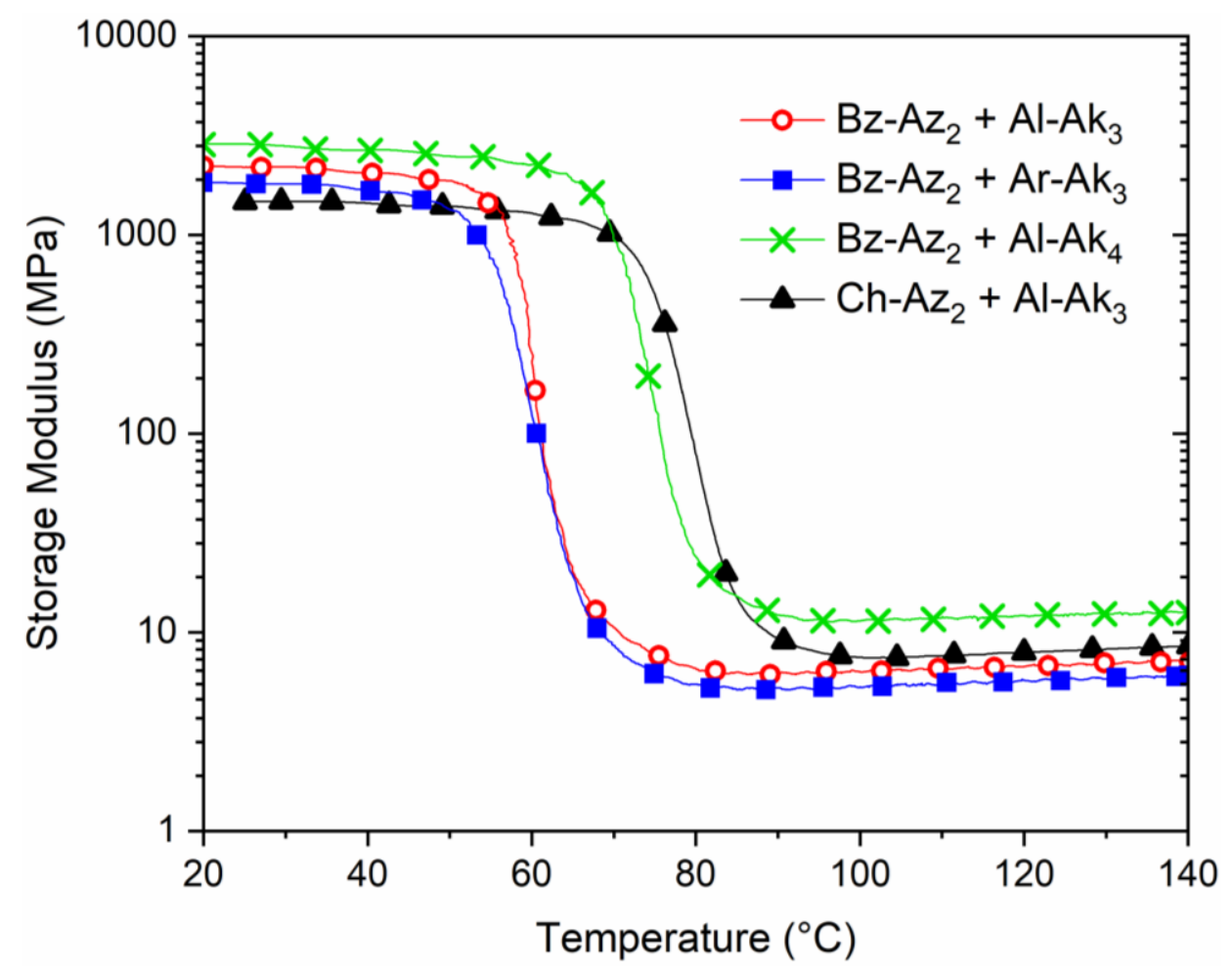

Figure S8. Storage modulus of the four crosslinked systems (structures shown in Figure 1) as measured by DMTA. The resins (denoted as Bz-Az $z_{2}+\mathrm{Al}-\mathrm{Ak}_{3}, \mathrm{Bz}-\mathrm{Az}_{2}+\mathrm{Ar}-\mathrm{Ak}_{3}, \mathrm{Bz}-\mathrm{Az}_{2}+\mathrm{Al}-\mathrm{Ak}_{4}$, and $\mathrm{Ch}-\mathrm{Az}_{2}+$

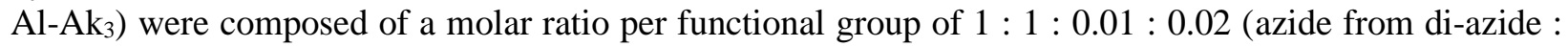
alkyne from tri-alkyne : $\mathrm{CuCl}_{2}$ [PMDETA] : DMPA). Each mixture was irradiated at room temperature using $10 \mathrm{~mW} \mathrm{~cm}{ }^{-2}$ of UV light $\left(\lambda_{\max }=366 \mathrm{~nm}\right)$ for 5 min followed by post cure at $70-80{ }^{\circ} \mathrm{C}$ for $24-48$ hours. 

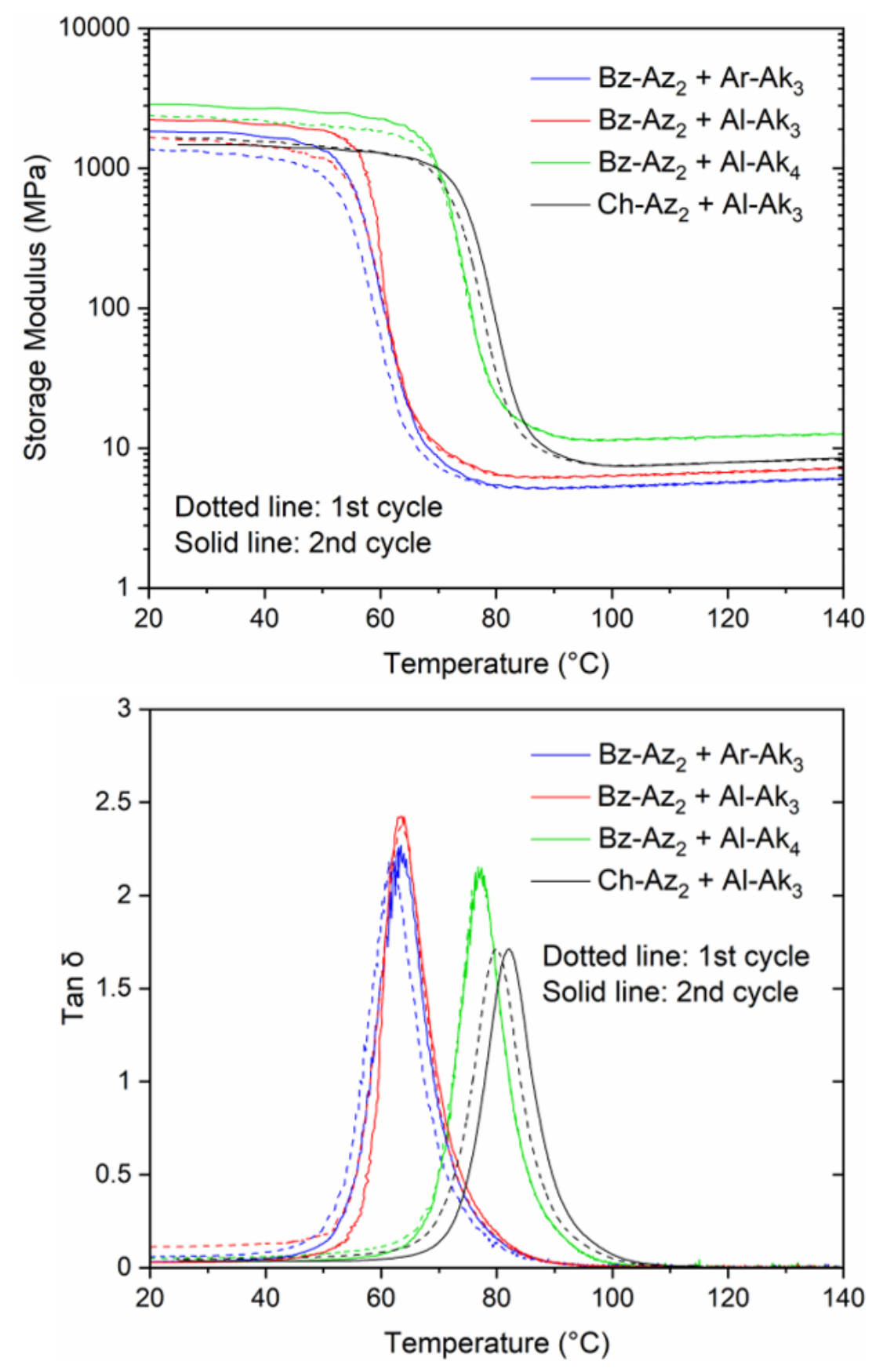

Figure S9. Thermo-mechanical properties of the four crosslinked systems (structures shown in Figure 1) as measured by DMTA. The resins (denoted as $\mathrm{Bz}-\mathrm{Az}_{2}+\mathrm{Ar}-\mathrm{Ak}_{3}, \mathrm{Bz}-\mathrm{Az}_{2}+\mathrm{Al}-\mathrm{Ak}_{3}, \mathrm{Bz}-\mathrm{Az}_{2}+\mathrm{Al}_{-}-\mathrm{Ak}_{4}$, and $\mathrm{Ch}-\mathrm{Az}_{2}+\mathrm{Al}-\mathrm{Ak}_{3}$ ) were composed of a molar ratio per functional group of $1: 1: 0.01: 0.02$ (azide from di-azide : alkyne from tri-alkyne : $\mathrm{CuCl}_{2}$ [PMDETA] : DMPA). Each mixture was irradiated at room temperature using $10 \mathrm{~mW} \mathrm{~cm}{ }^{-2}$ of UV light $\left(\lambda_{\max }=366 \mathrm{~nm}\right)$ for 5 min followed by post cure at $70-80{ }^{\circ} \mathrm{C}$ for 24-48 hours. The near overlap of the data for the first (dotted line) and second DMTA scans (solid line) indicates that nearly complete solvent removal and chemical cure were achieved after photopolymerization and the subsequent thermal post-cure. 
Table S1. A summary of the tensile testing properties using a crosshead rate of $0.75 \mathrm{~mm} \mathrm{~min}^{-1}$ (a strain rate of $5 \% \mathrm{~min}^{-1}$ ) and DMTA mechanical behavior for the four different crosslinked systems from Figure 1. Errors listed for the tensile testing data are the SD obtained from multiple measurements $(\mathrm{n} \geq 4)$. Average values are reported for DMTA data based on two measurements.

\begin{tabular}{|c|c|c|c|c|}
\hline & $\begin{array}{c}\mathrm{Bz}-\mathrm{Az}_{2}+ \\
\mathrm{Ar}-\mathrm{Ak}_{3}\end{array}$ & $\begin{array}{c}\mathrm{Bz}-\mathrm{Az}_{2}+ \\
\mathrm{Al}-\mathrm{Ak}_{3}\end{array}$ & $\begin{array}{c}\mathrm{Bz}-\mathrm{Az}_{2}+ \\
\mathrm{Al}-\mathrm{Ak}_{4}\end{array}$ & $\begin{array}{c}\mathrm{Ch}-\mathrm{Az}_{2}+ \\
\mathrm{Al}-\mathrm{Ak}_{3}\end{array}$ \\
\hline $\mathrm{T}_{\mathrm{g}}$ from $\tan \delta$ maximum $\left({ }^{\circ} \mathrm{C}\right)$ & 62 & 65 & 75 & 81 \\
\hline Storage modulus@ $25^{\circ} \mathrm{C}(\mathrm{GPa})$ & 1.4 & 2.2 & 1.9 & 1.7 \\
\hline Storage modulus@ $\mathrm{T}_{\mathrm{g}}+30^{\circ} \mathrm{C}(\mathrm{MPa})$ & 4.7 & 6 & 9 & 8 \\
\hline Network strand density, $v\left(\mathrm{mmol} \mathrm{g}^{-1}\right)$ & 0.52 & 0.65 & 0.95 & 0.84 \\
\hline Average molecular weight per strand, $\mathrm{M}_{\mathrm{c}}\left(\mathrm{g} \mathrm{mol}^{-1}\right)^{*}$ & 1940 & 1530 & 1050 & 1200 \\
\hline Tensile yield stress (MPa) & $29 \pm 2$ & $36 \pm 3$ & $43 \pm 2$ & $40 \pm 2$ \\
\hline Tensile Young's modulus (MPa) & $780 \pm 70$ & $960 \pm 40$ & $1000 \pm 50$ & $850 \pm 60$ \\
\hline Tensile toughness $\left(\mathrm{MJ} \mathrm{m}^{-3}\right)$ & $61 \pm 10$ & $53 \pm 6$ & $29 \pm 2$ & $40 \pm 4$ \\
\hline Tensile elongation at break $(\%)$ & $200 \pm 30$ & $160 \pm 7$ & $80 \pm 2$ & $110 \pm 10$ \\
\hline
\end{tabular}

* Calculated from the affine theory of rubber elasticity ${ }^{4}$ given by $\mathrm{E}=3 v \mathrm{dRT}$, where $\mathrm{E}$ is the rubbery modulus, $\mathrm{d}$ is the density of a sample (assumed to $1 \mathrm{~g} / \mathrm{cm}^{3}$ ), $\mathrm{R}$ is the gas constant, $\mathrm{T}$ is the temperature at rubbery plateau, $v$ is the network strand density and $M_{c}=1 / v$. 


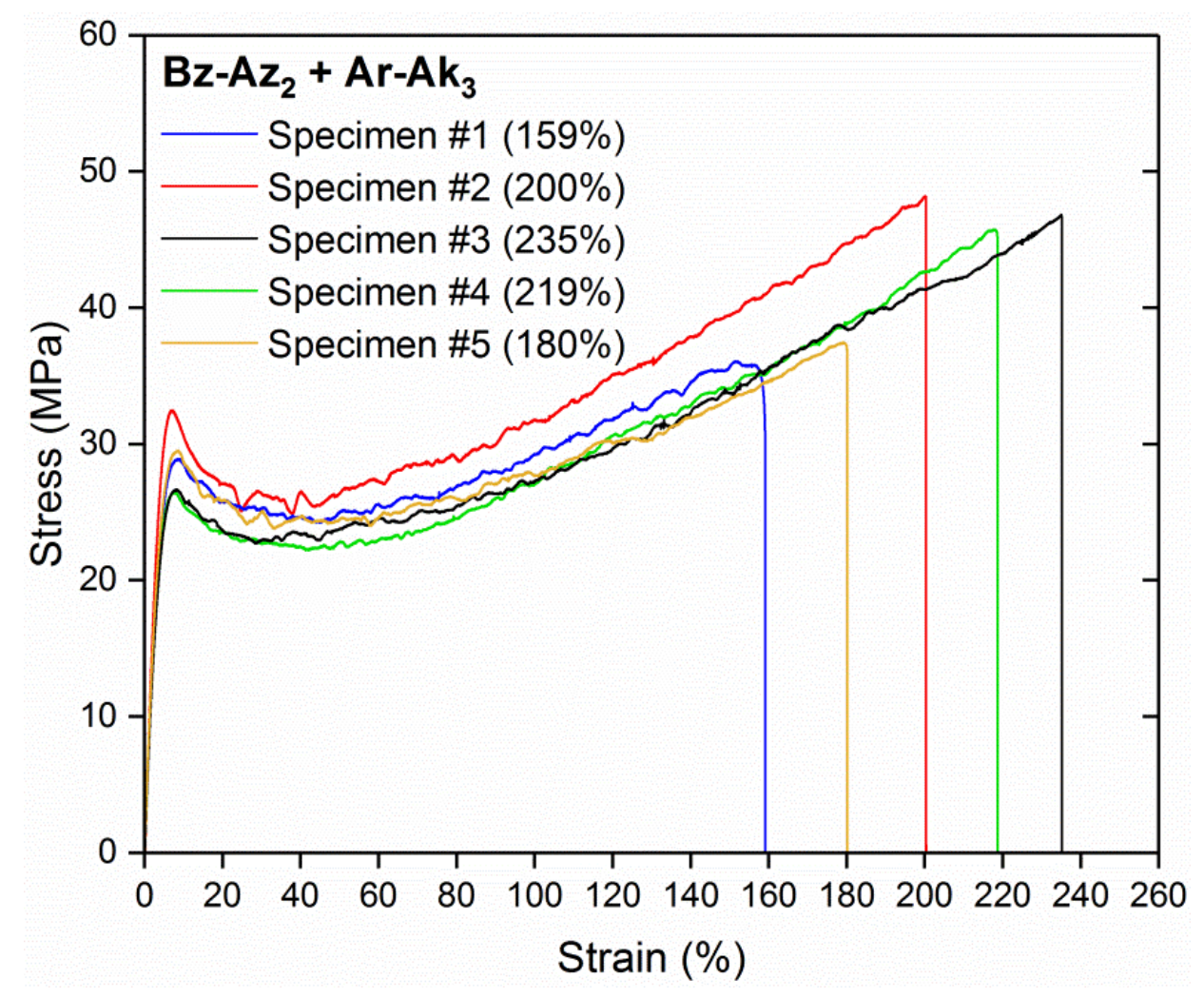

Figure S10. Tensile testing of the $\mathrm{Bz}-\mathrm{Az}_{2}+\mathrm{Ar}-\mathrm{Ak}_{3}$ system in Figure 1 at a crosshead rate of $0.75 \mathrm{~mm}$ $\min ^{-1}$ (a strain rate of $5 \% \mathrm{~min}^{-1}$ ) using the MTS instrument. The resin was composed of a molar ratio per functional group of $1: 1: 0.01: 0.02$ (azide from di-azide : alkyne from tri-alkyne : $\mathrm{CuCl}_{2}$ [PMDETA] : DMPA). Each mixture was irradiated at room temperature using $10 \mathrm{~mW} \mathrm{~cm}^{-2}$ of UV light $\left(\lambda_{\max }=366 \mathrm{~nm}\right)$ for 5 min followed by post cure at $70-80{ }^{\circ} \mathrm{C}$ for $24-48$ hours. Each specimen was heated above $\mathrm{T}_{\mathrm{g}}$ for 1 minute followed by 3 minutes of cooling at ambient temperature prior to mechanical testing. 


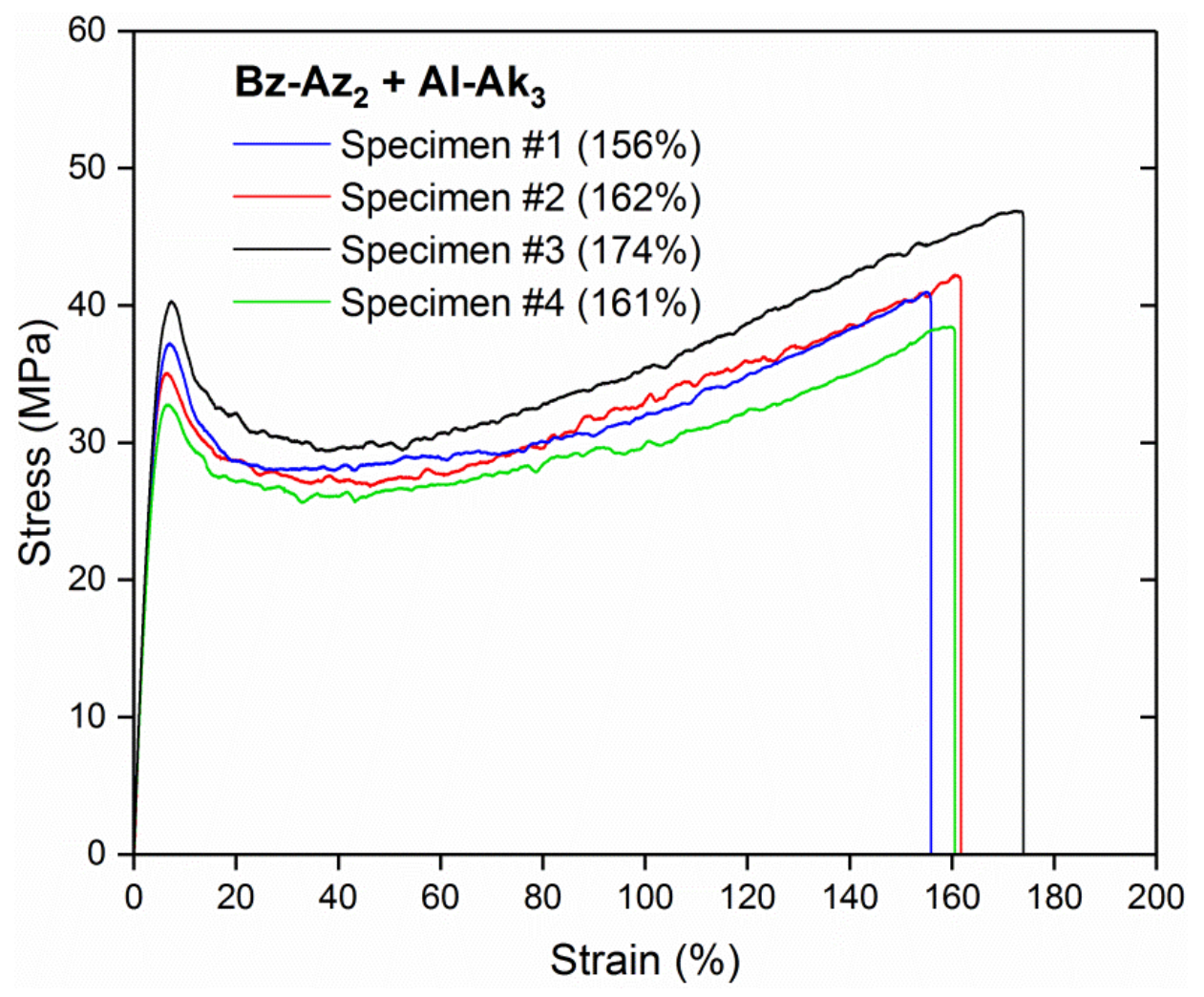

Figure S11. Tensile testing of the $\mathrm{Bz}-\mathrm{Az}_{2}+\mathrm{Al}_{-} \mathrm{Ak}_{3}$ system in Figure 1 at a crosshead rate of $0.75 \mathrm{~mm}$ $\min ^{-1}$ (a strain rate of $5 \% \mathrm{~min}^{-1}$ ) using the MTS instrument. The resin was composed of a molar ratio per functional group of $1: 1: 0.01: 0.02$ (azide from di-azide : alkyne from tri-alkyne : $\mathrm{CuCl}_{2}$ [PMDETA] : DMPA). Each mixture was irradiated at room temperature using $10 \mathrm{~mW} \mathrm{~cm}^{-2}$ of UV light $\left(\lambda_{\max }=366 \mathrm{~nm}\right)$ for $5 \mathrm{~min}$ followed by post cure at $70-80{ }^{\circ} \mathrm{C}$ for $24-48$ hours. Each specimen was heated above $\mathrm{T}_{\mathrm{g}}$ for 1 minute followed by 3 minutes of cooling at ambient temperature prior to mechanical testing. 


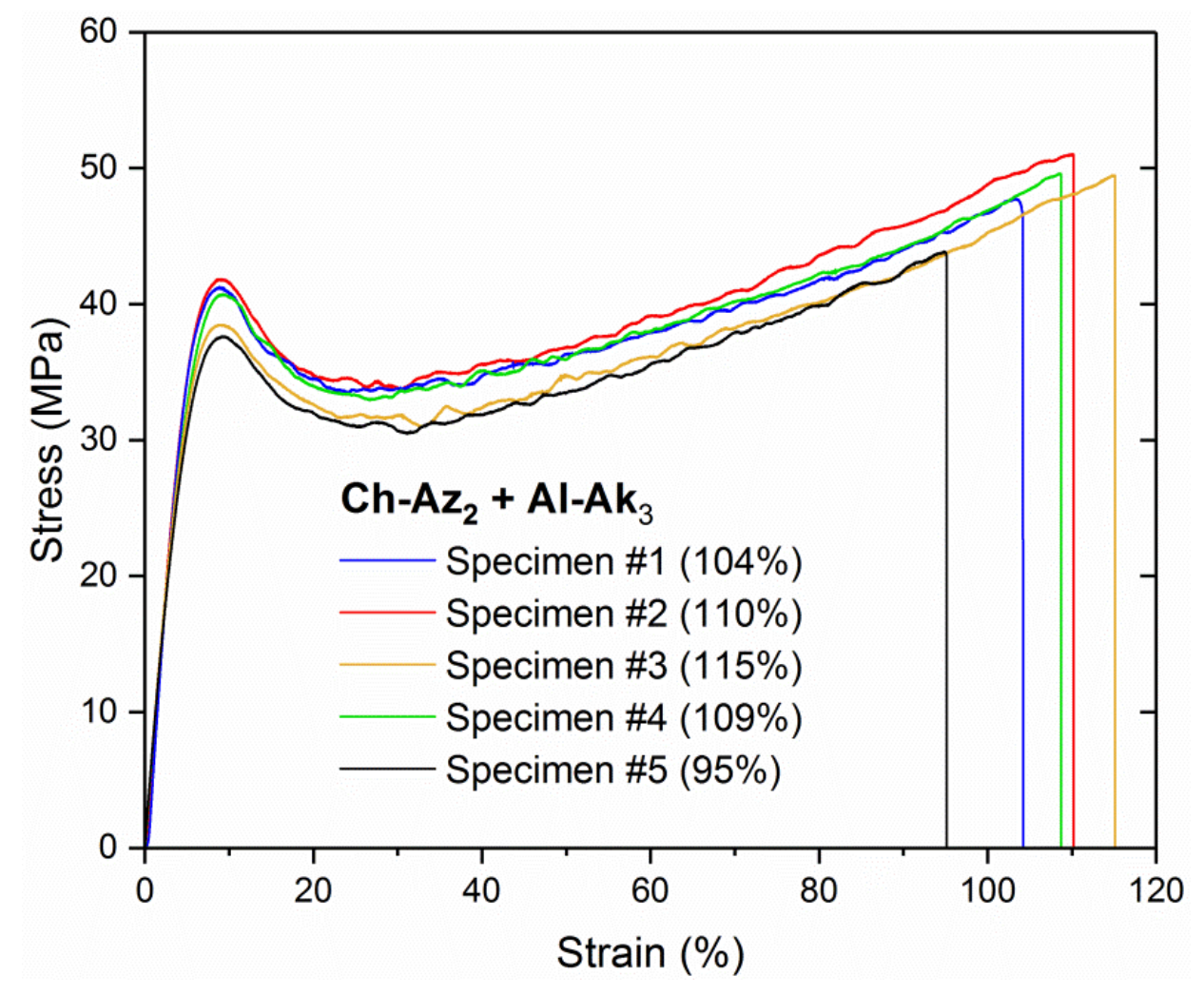

Figure S12. Tensile testing of the $\mathrm{Ch}-\mathrm{Az}_{2}+\mathrm{Al}-\mathrm{Ak}_{3}$ system in Figure 1 at a crosshead rate of $0.75 \mathrm{~mm}$ $\min ^{-1}$ (a strain rate of $5 \% \mathrm{~min}^{-1}$ ) using the MTS instrument. The resin was composed of a molar ratio per functional group of $1: 1: 0.01: 0.02$ (azide from di-azide : alkyne from tri-alkyne : $\mathrm{CuCl}_{2}$ [PMDETA] : DMPA). Each mixture was irradiated at room temperature using $10 \mathrm{~mW} \mathrm{~cm}^{-2}$ of UV light $\left(\lambda_{\max }=366 \mathrm{~nm}\right)$ for $5 \mathrm{~min}$ followed by post cure at $70-80{ }^{\circ} \mathrm{C}$ for $24-48$ hours. Each specimen was heated above $\mathrm{T}_{\mathrm{g}}$ for 1 minute followed by 3 minutes of cooling at ambient temperature prior to mechanical testing. 


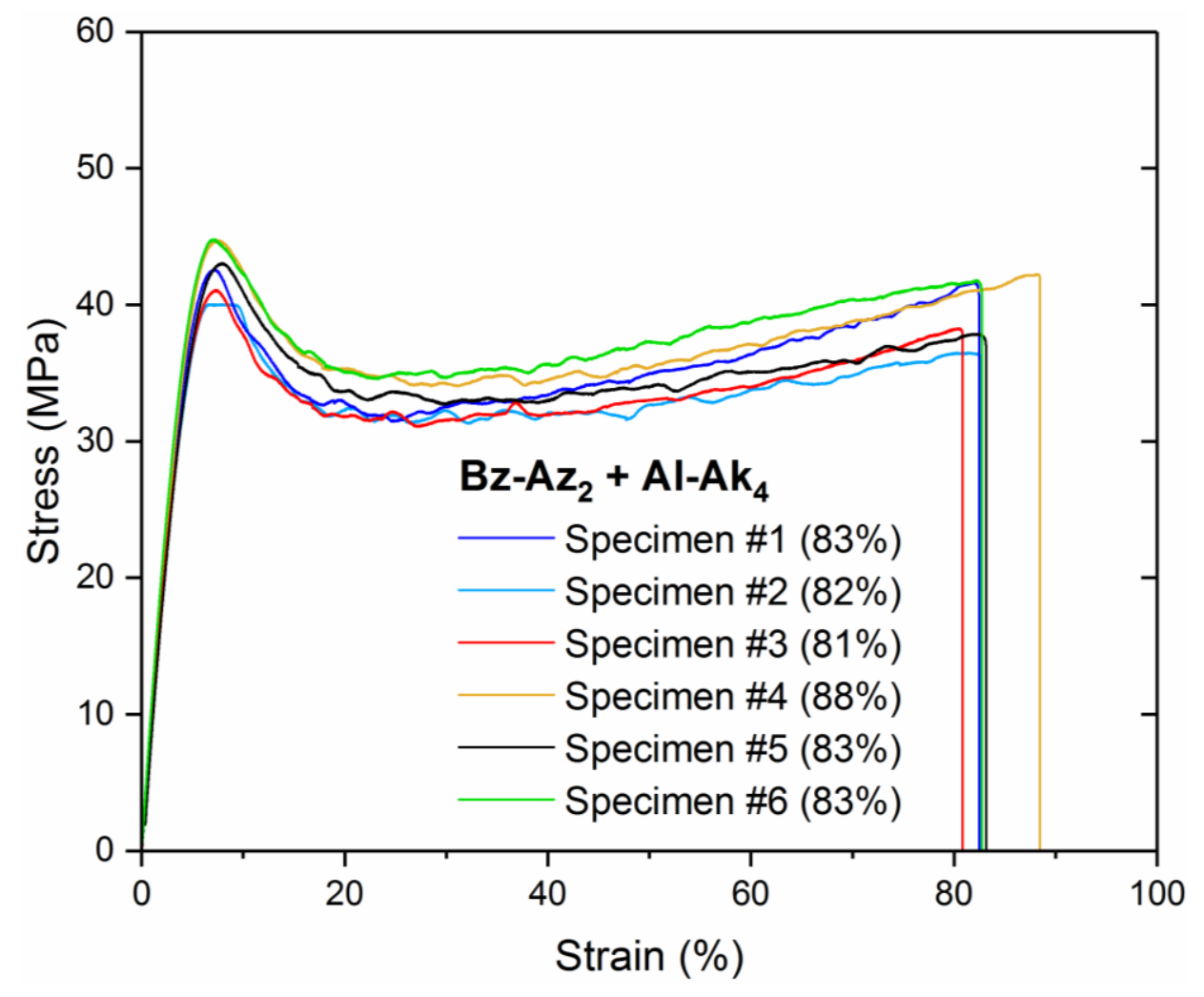

Figure S13. Tensile testing of the $\mathrm{Bz}-\mathrm{Az}_{2}+\mathrm{Al}_{-} \mathrm{Ak}_{4}$ system in Figure 1 at a crosshead rate of $0.75 \mathrm{~mm}$ $\min ^{-1}$ (a strain rate of $5 \% \mathrm{~min}^{-1}$ ) using the MTS instrument. The resin was composed of a molar ratio per functional group of $1: 1: 0.01: 0.02$ (azide from di-azide : alkyne from tri-alkyne : $\mathrm{CuCl}_{2}$ [PMDETA] : DMPA). Each mixture was irradiated at room temperature using $10 \mathrm{~mW} \mathrm{~cm}^{-2}$ of $U V$ light $\left(\lambda_{\max }=366 \mathrm{~nm}\right)$ for $5 \mathrm{~min}$ followed by post cure at $70-80{ }^{\circ} \mathrm{C}$ for $24-48$ hours. Each specimen was heated above $\mathrm{T}_{\mathrm{g}}$ for 1 minute followed by 3 minutes of cooling at ambient temperature prior to mechanical testing. 


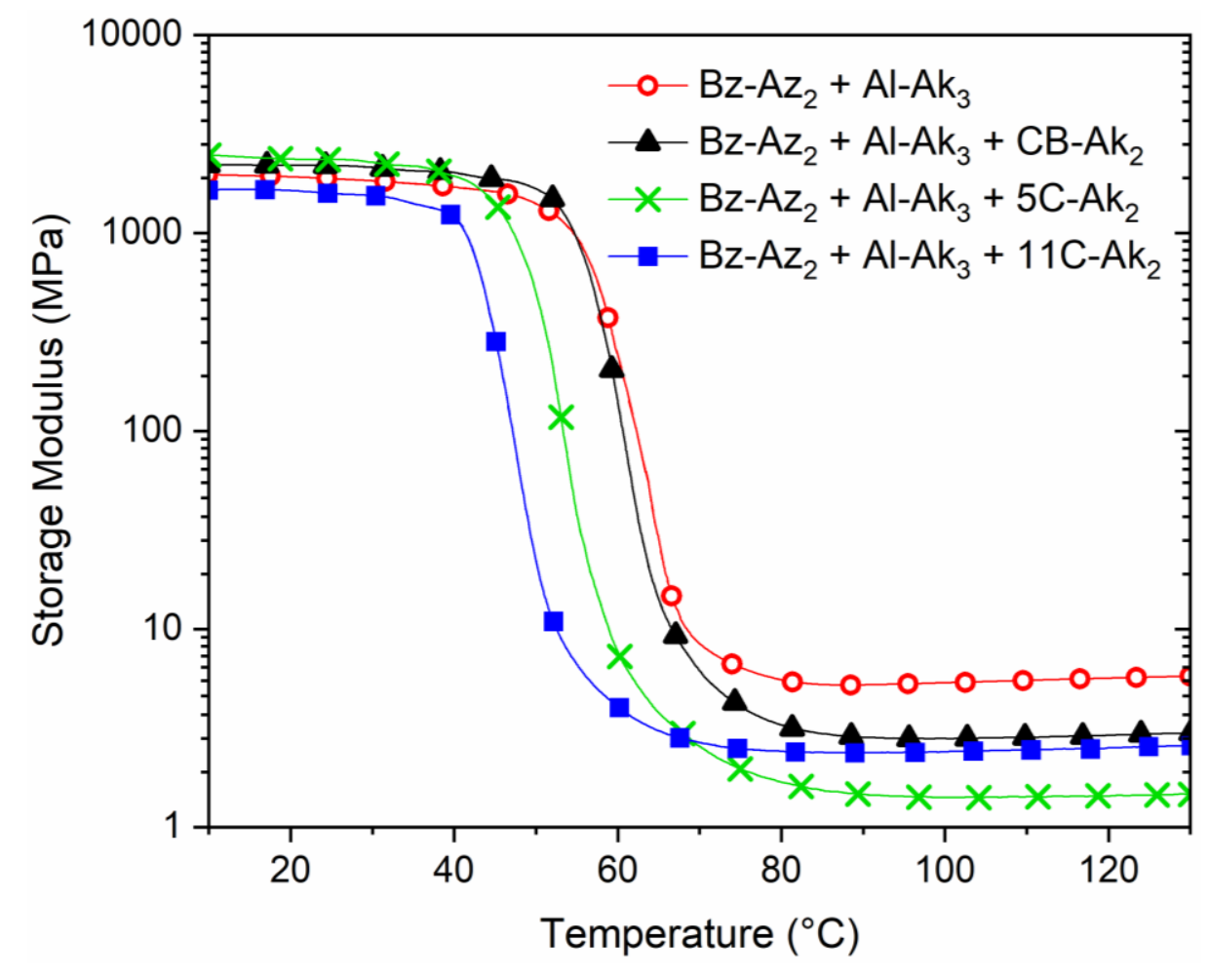

Figure S14. Storage modulus of the four crosslinked systems (structures shown in Figure 2) as measured by DMTA. The resin (denoted as $\mathrm{Bz}-\mathrm{Az}_{2}+\mathrm{Al}-\mathrm{Ak}_{3}$ ) was composed of a molar ratio per functional group of $1: 1: 0.01: 0.02$ (azide from di-azide : alkyne from tri-alkyne : $\mathrm{CuCl}_{2}$ [PMDETA] : DMPA). The resins $\left(\mathrm{Bz}-\mathrm{Az}_{2}+\mathrm{Al}-\mathrm{Ak}_{3}+\mathrm{CB}-\mathrm{Ak}_{2}, \mathrm{Bz}-\mathrm{Az}_{2}+\mathrm{Al}-\mathrm{Ak}_{3}+5 \mathrm{C}-\mathrm{Ak}_{2}\right.$, and $\left.\mathrm{Bz}-\mathrm{Az} \mathrm{z}_{2}+\mathrm{Al}-\mathrm{Ak}_{3}+11 \mathrm{C}-\mathrm{Ak}_{2}\right)$ were composed of a molar ratio per functional group of $1: 0.5: 0.5: 0.01: 0.02$ (azide from di-azide : alkyne from tri-alkyne : alkyne from di-alkyne : $\mathrm{CuCl}_{2}$ [PMDETA] : DMPA). Each mixture was irradiated at room temperature using $10 \mathrm{~mW} \mathrm{~cm} \mathrm{~cm}^{-2}$ of UV light $\left(\lambda_{\max }=366 \mathrm{~nm}\right)$ for $5 \mathrm{~min}$ followed by post cure at 70 $80{ }^{\circ} \mathrm{C}$ for $24-48$ hours. 

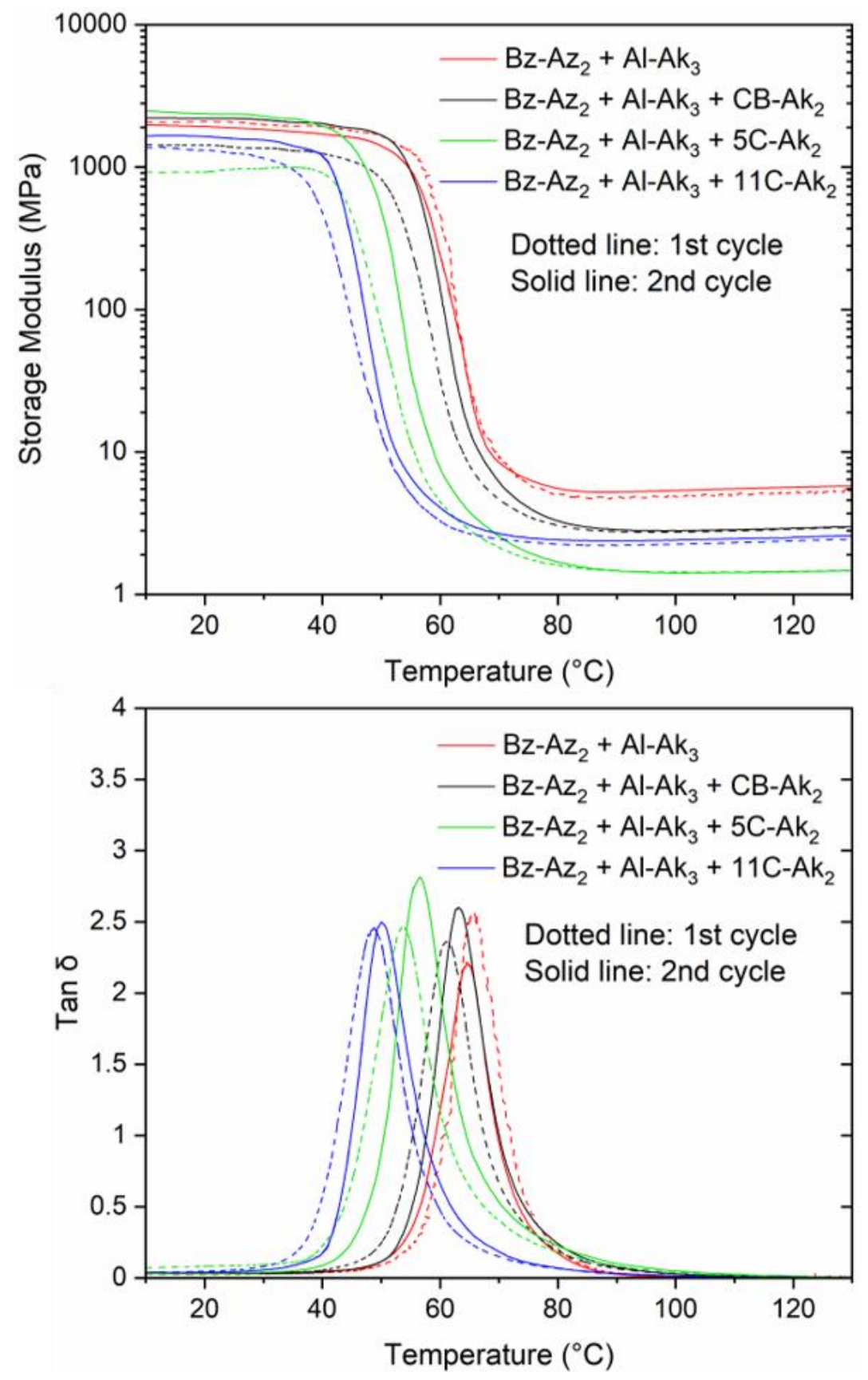

Figure S15. Thermo-mechanical properties of the four crosslinked systems (structures shown in Figure 2) as measured by DMTA. The resin (denoted as $\mathrm{Bz}-\mathrm{Az}_{2}+\mathrm{Al}-\mathrm{Ak}_{3}$ ) was composed of a molar ratio per functional group of $1: 1: 0.01: 0.02$ (azide from di-azide : alkyne from tri-alkyne : $\mathrm{CuCl}_{2}$ [PMDETA] : DMPA). The resins (denoted as Bz-Az $+\mathrm{Al}-\mathrm{Ak}_{3}+\mathrm{CB}-\mathrm{Ak}_{2}, \mathrm{Bz}-\mathrm{Az} z_{2}+\mathrm{Al}-\mathrm{Ak}_{3}+5 \mathrm{C}-\mathrm{Ak}_{2}$, and Bz-Az $2+$

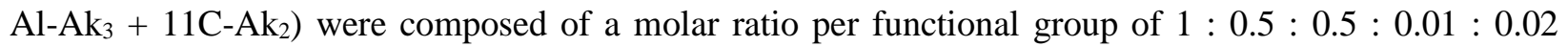
(azide from di-azide : alkyne from tri-alkyne : alkyne from di-alkyne : $\mathrm{CuCl}_{2}$ [PMDETA] : DMPA). Each mixture was irradiated at room temperature using $10 \mathrm{~mW} \mathrm{~cm}{ }^{-2}$ of UV light $\left(\lambda_{\max }=366 \mathrm{~nm}\right)$ for $5 \mathrm{~min}$ followed by post cure at $70-80{ }^{\circ} \mathrm{C}$ for $24-48$ hours. The near overlap of the data for the first (dotted line) and second DMTA scans (solid line) indicates that nearly complete solvent removal and chemical cure were achieved after photopolymerization and the subsequent thermal post-cure. 
Table S2. A summary of tensile testing properties using crosshead rates of $0.75 \mathrm{~mm} \mathrm{~min}^{-1}$ and $7.5 \mathrm{~mm}$ $\min ^{-1}$ (strain rates of $5 \% \mathrm{~min}^{-1}$ and $50 \% \mathrm{~min}^{-1}$ ) and DMTA mechanical behavior for the four different crosslinked systems from Figure 2. Errors listed for the tensile testing data at a crosshead rate of $0.75 \mathrm{~mm}$ $\min ^{-1}$ are the SD obtained from multiple measurements $(\mathrm{n} \geq 3)$ for $\mathrm{Bz}-\mathrm{Az} \mathrm{z}_{2}+\mathrm{Al}-\mathrm{Ak}_{3}$ and $\mathrm{Bz}-\mathrm{Az}_{2}+\mathrm{Al}-\mathrm{Ak}_{3}$ $+5 \mathrm{C}-\mathrm{Ak}_{2}$ and two measurements $(\mathrm{n}=2)$ for $\mathrm{Bz}-\mathrm{Az} z_{2}+\mathrm{Al}-\mathrm{Ak}_{3}+\mathrm{CB}-\mathrm{Ak}_{2}$ and $\mathrm{Bz}-\mathrm{Az}_{2}+\mathrm{Al}-\mathrm{Ak}_{3}+11 \mathrm{C}-\mathrm{Ak}_{2}$. Errors listed for the tensile testing data at a crosshead rate of $7.5 \mathrm{~mm} \mathrm{~min}^{-1}$ are the SD obtained from multiple measurements $(\mathrm{n} \geq 3)$. Reported values for DMTA data are based on an average of two measurements for $\mathrm{Bz}-\mathrm{Az}_{2}+\mathrm{Al}-\mathrm{Ak}_{3}+\mathrm{CB}-\mathrm{Ak}_{2}$ and $\mathrm{Bz}-\mathrm{Az}_{2}+\mathrm{Al}-\mathrm{Ak}_{3}+11 \mathrm{C}-\mathrm{Ak}_{2}$, and a single measurement for $\mathrm{Bz}-\mathrm{Az}_{2}+\mathrm{Al}-\mathrm{Ak}_{3}$ and $\mathrm{Bz}-\mathrm{Az}_{2}+\mathrm{Al}-\mathrm{Ak}_{3}+5 \mathrm{C}-\mathrm{Ak}_{2}$.

\begin{tabular}{|c|c|c|c|c|}
\hline & $\begin{array}{c}\mathrm{Bz}-\mathrm{Az}_{2}+ \\
\mathrm{Al}-\mathrm{Ak}_{3}\end{array}$ & $\begin{array}{c}\mathrm{Bz}-\mathrm{Az}_{2}+ \\
\mathrm{Al}-\mathrm{Ak}_{3}+ \\
\mathrm{CB}-\mathrm{Ak}_{2}\end{array}$ & $\begin{array}{c}\mathrm{Bz}-\mathrm{Az}_{2}+ \\
\mathrm{Al}-\mathrm{Ak}_{3}+ \\
5 \mathrm{C}-\mathrm{Ak}_{2}\end{array}$ & $\begin{array}{l}\mathrm{Bz}-\mathrm{Az}_{2}+ \\
\mathrm{Al}-\mathrm{Ak}_{3}+ \\
11 \mathrm{C}-\mathrm{Ak}_{2}\end{array}$ \\
\hline $\mathrm{T}_{\mathrm{g}}$ from $\tan \delta$ maximum $\left({ }^{\circ} \mathrm{C}\right)$ & 65 & 62 & 55 & 49 \\
\hline Storage modulus@25 ${ }^{\circ} \mathrm{C}(\mathrm{GPa})$ & 2 & 1.7 & 1.7 & 1.6 \\
\hline Storage modulus@ $\mathrm{T}_{\mathrm{g}}+30^{\circ} \mathrm{C}(\mathrm{MPa})$ & 5.1 & 2.9 & 1.5 & 2.6 \\
\hline Network strand density, $v\left(\mathrm{mmol} \mathrm{g}^{-1}\right)$ & 0.56 & 0.32 & 0.17 & 0.3 \\
\hline Average molecular weight per strand, $\mathrm{M}_{\mathrm{c}}\left(\mathrm{g} \mathrm{mol}^{-1}\right)^{*}$ & 1800 & 3140 & 5950 & 3380 \\
\hline Tensile yield stress $(\mathrm{MPa})$ at $0.75 \mathrm{~mm} \mathrm{~min}^{-1}$ & $36 \pm 1$ & $33 \pm 1$ & $23 \pm 3$ & $16.0 \pm 0.4$ \\
\hline Tensile yield stress $(\mathrm{MPa})$ at $7.5 \mathrm{~mm} \mathrm{~min}^{-1}$ & $51 \pm 1$ & $45 \pm 3$ & $42 \pm 1$ & $33 \pm 3$ \\
\hline Tensile Young's modulus (MPa) at $0.75 \mathrm{~mm} \mathrm{~min}^{-1}$ & $1030 \pm 130$ & $850 \pm 40$ & $590 \pm 80$ & $470 \pm 80$ \\
\hline Tensile Young's modulus (MPa) at $7.5 \mathrm{~mm} \mathrm{~min}^{-1}$ & $1140 \pm 50$ & $990 \pm 100$ & $990 \pm 140$ & $860 \pm 50$ \\
\hline Tensile toughness $\left(\mathrm{MJ} \mathrm{m}^{-3}\right)$ at $0.75 \mathrm{~mm} \mathrm{~min}^{-1}$ & $48 \pm 7$ & $51 \pm 5$ & $54 \pm 7$ & $44 \pm 3$ \\
\hline Tensile toughness $\left(\mathrm{MJ} \mathrm{m}^{-3}\right)$ at $7.5 \mathrm{~mm} \mathrm{~min}^{-1}$ & $32 \pm 2$ & $45 \pm 17$ & $58 \pm 10$ & $67 \pm 2$ \\
\hline Tensile elongation at break $(\%)$ at $0.75 \mathrm{~mm} \mathrm{~min}^{-1}$ & $166 \pm 14$ & $200 \pm 18$ & $300 \pm 10$ & $300 \pm 13$ \\
\hline Tensile elongation at break (\%) at $7.5 \mathrm{~mm} \mathrm{~min}^{-1}$ & $100 \pm 7$ & $150 \pm 50$ & $230 \pm 30$ & $300 \pm 20$ \\
\hline
\end{tabular}

* Calculated from the affine theory of rubber elasticity ${ }^{4}$ given by $\mathrm{E}=3 v \mathrm{dRT}$, where $\mathrm{E}$ is the rubbery modulus, $\mathrm{d}$ is the density of a sample (assumed to $1 \mathrm{~g} / \mathrm{cm}^{3}$ ), $\mathrm{R}$ is the gas constant, $\mathrm{T}$ is the temperature at rubbery plateau, $v$ is the network strand density and $M_{c}=1 / v$. 


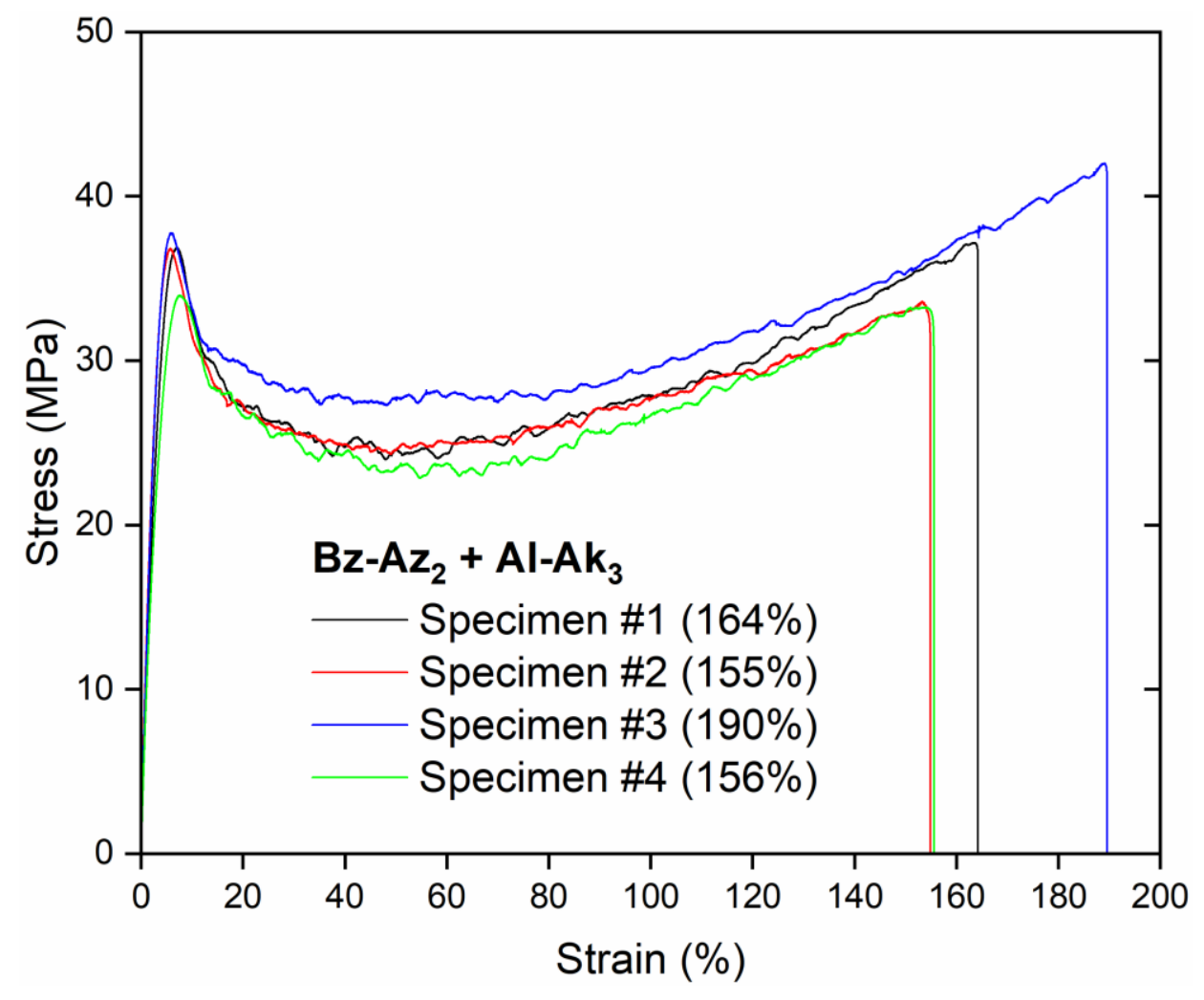

Figure S16. Tensile testing of the $\mathrm{Bz}_{-} \mathrm{Az}_{2}+\mathrm{Al}_{-} \mathrm{Ak}_{3}$ system in Figure 2 at a crosshead rate of $0.75 \mathrm{~mm}$ $\mathrm{min}^{-1}$ (a strain rate of $5 \% \mathrm{~min}^{-1}$ ) using the MTS instrument. The resin was composed of a molar ratio per functional group of $1: 1: 0.01: 0.02$ (azide from di-azide : alkyne from tri-alkyne : $\mathrm{CuCl}_{2}$ [PMDETA] : DMPA). Each mixture was irradiated at room temperature using $10 \mathrm{~mW} \mathrm{~cm}^{-2}$ of UV light $\left(\lambda_{\max }=366 \mathrm{~nm}\right)$ for 5 min followed by post cure at $70-80{ }^{\circ} \mathrm{C}$ for $24-48$ hours. Each specimen was heated above $\mathrm{T}_{\mathrm{g}}$ for 1 minute followed by 3 minutes of cooling at ambient temperature prior to mechanical testing. 


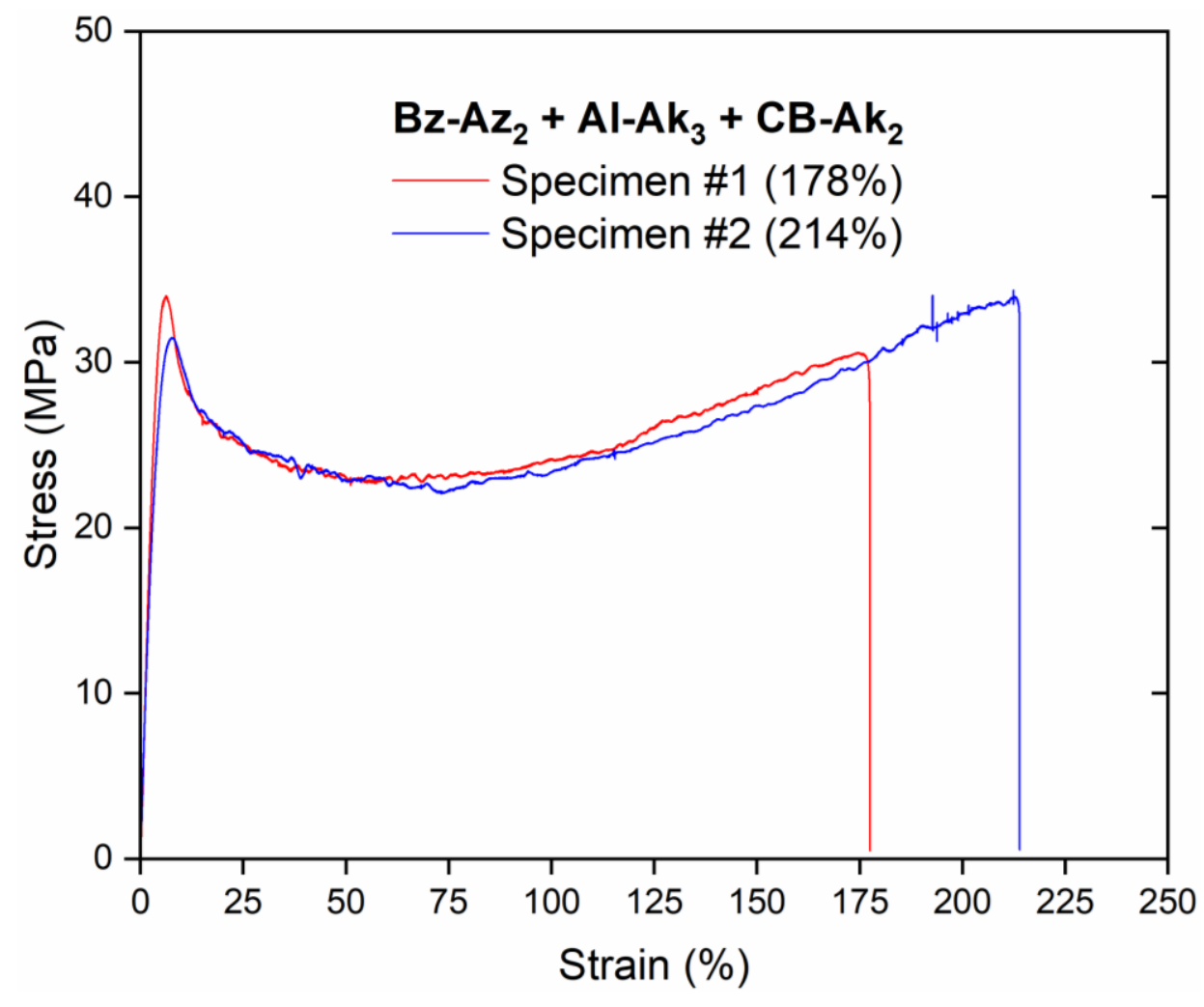

Figure S17. Tensile testing of the $\mathrm{Bz}-\mathrm{Az} \mathrm{z}_{2}+\mathrm{Al}-\mathrm{Ak}_{3}+\mathrm{CB}-\mathrm{Ak}_{2}$ system in Figure 2 at a crosshead rate of $0.75 \mathrm{~mm} \mathrm{~min}^{-1}$ (a strain rate of $5 \% \mathrm{~min}^{-1}$ ) using the MTS instrument. The resin was composed of a molar ratio per functional group of $1: 0.5: 0.5: 0.01: 0.02$ (azide from di-azide : alkyne from tri-alkyne : alkyne from di-alkyne : $\mathrm{CuCl}_{2}$ [PMDETA] : DMPA). Each mixture was irradiated at room temperature using $10 \mathrm{~mW} \mathrm{~cm}{ }^{-2}$ of UV light $\left(\lambda_{\max }=366 \mathrm{~nm}\right)$ for 5 min followed by post cure at $70-80{ }^{\circ} \mathrm{C}$ for $24-48$ hours. Each specimen was heated above $\mathrm{T}_{\mathrm{g}}$ for 1 minute followed by 3 minutes of cooling at ambient temperature prior to mechanical testing. 


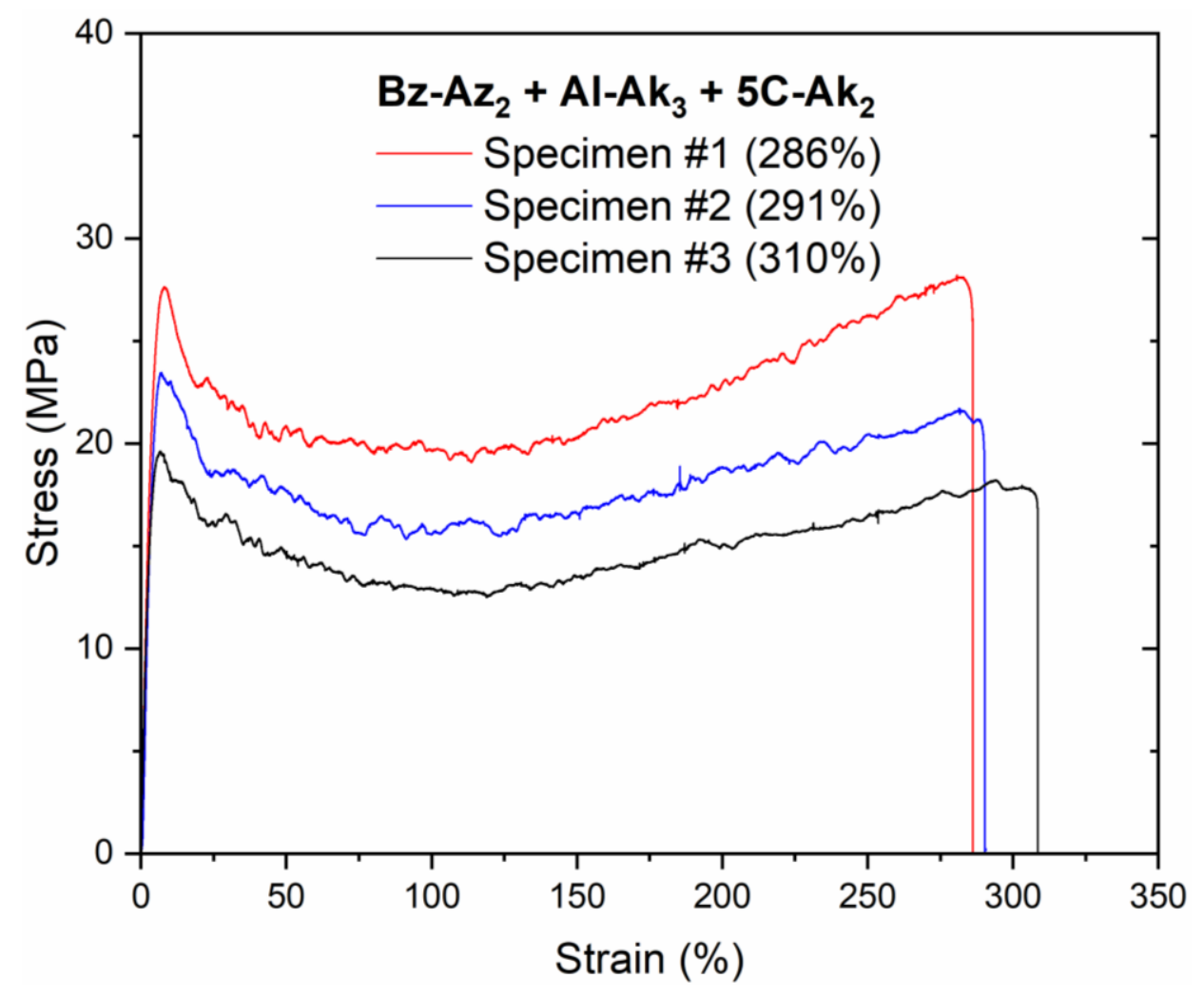

Figure S18. Tensile testing of the $\mathrm{Bz}-\mathrm{Az} \mathrm{z}_{2}+\mathrm{Al}-\mathrm{Ak}_{3}+5 \mathrm{C}-\mathrm{Ak}_{2}$ system in Figure 2 at a crosshead rate of $0.75 \mathrm{~mm} \mathrm{~min}^{-1}$ (a strain rate of $5 \% \mathrm{~min}^{-1}$ ) using the MTS instrument. The resin was composed of a molar ratio per functional group of $1: 0.5: 0.5: 0.01: 0.02$ (azide from di-azide : alkyne from tri-alkyne : alkyne from di-alkyne : $\mathrm{CuCl}_{2}$ [PMDETA] : DMPA). Each mixture was irradiated at room temperature using $10 \mathrm{~mW} \mathrm{~cm}^{-2}$ of UV light $\left(\lambda_{\max }=366 \mathrm{~nm}\right)$ for 5 min followed by post cure at $70-80{ }^{\circ} \mathrm{C}$ for $24-48$ hours. Each specimen was heated above $\mathrm{T}_{\mathrm{g}}$ for 1 minute followed by 3 minutes of cooling at ambient temperature prior to mechanical testing. 


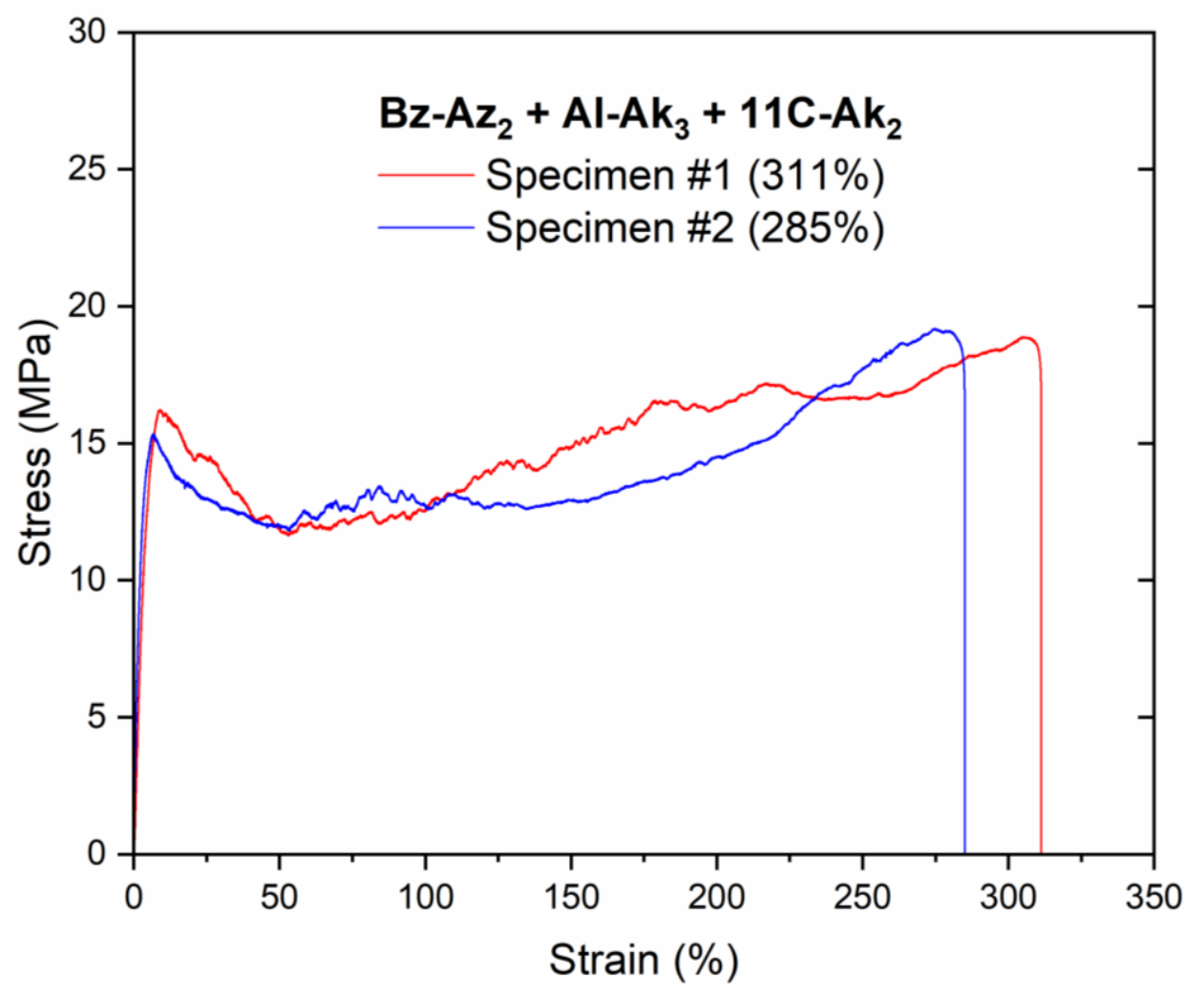

Figure S19. Tensile testing of the $\mathrm{Bz}-\mathrm{Az}_{2}+\mathrm{Al}-\mathrm{Ak}_{3}+11 \mathrm{C}-\mathrm{Ak}_{2}$ system in Figure 2 at a crosshead rate of $0.75 \mathrm{~mm} \mathrm{~min}^{-1}$ (a strain rate of $5 \% \mathrm{~min}^{-1}$ ) using the MTS instrument. The resin was composed of a molar ratio per functional group of $1: 0.5: 0.5: 0.01: 0.02$ (azide from di-azide : alkyne from tri-alkyne : alkyne from di-alkyne : $\mathrm{CuCl}_{2}$ [PMDETA] : DMPA). Each mixture was irradiated at room temperature using $10 \mathrm{~mW} \mathrm{~cm}^{-2}$ of UV light $\left(\lambda_{\max }=366 \mathrm{~nm}\right)$ for 5 min followed by post cure at $70-80{ }^{\circ} \mathrm{C}$ for $24-48$ hours. Each specimen was heated above $\mathrm{T}_{\mathrm{g}}$ for 1 minute followed by 3 minutes of cooling at ambient temperature prior to mechanical testing. 


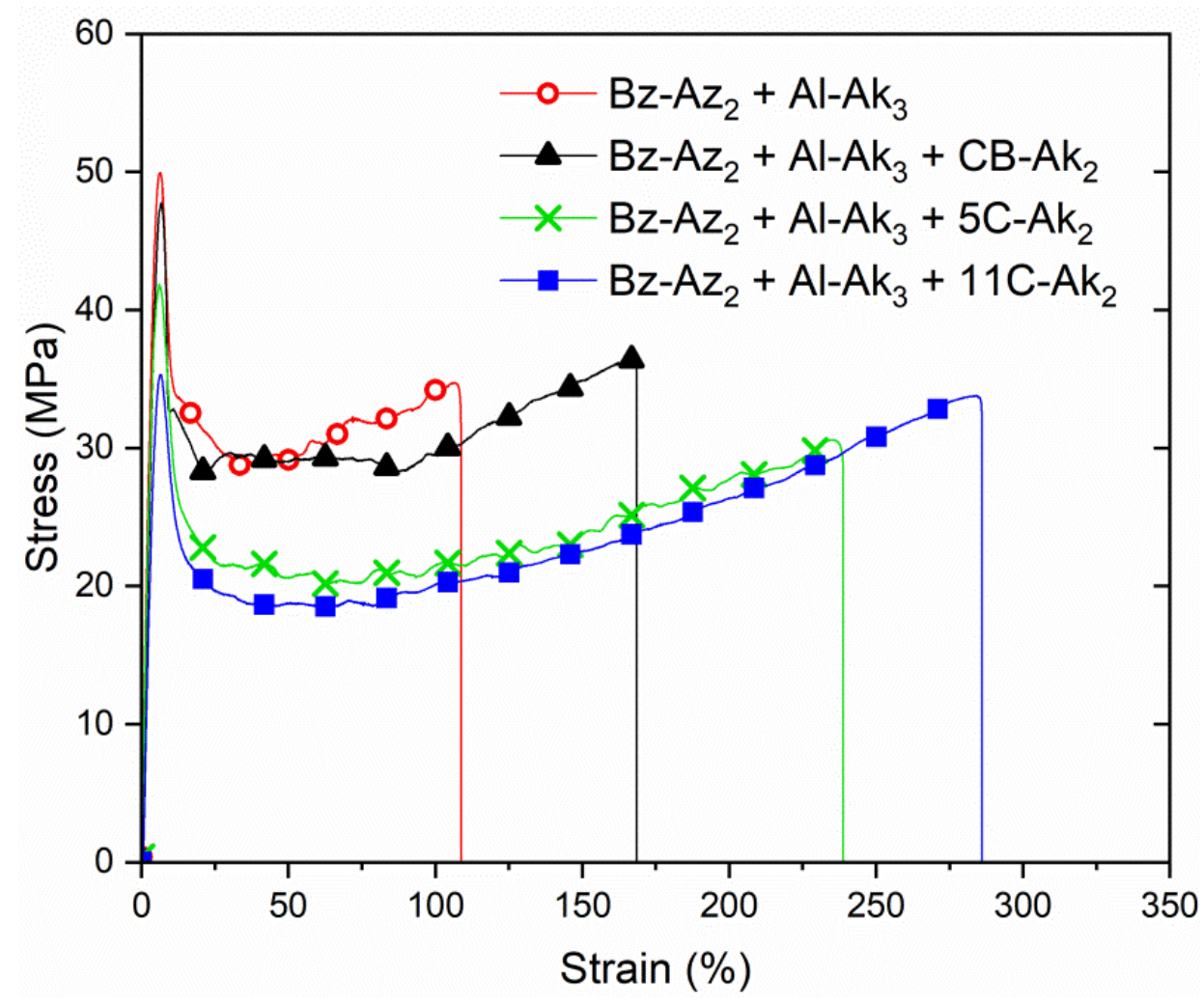

Figure S20. Tensile testing of the four crosslinked systems (structures shown in Figure 2) at a crosshead rate of $7.5 \mathrm{~mm} \mathrm{~min}^{-1}$ (a strain rate of $50 \% \mathrm{~min}^{-1}$ ) using the MTS instrument (for replicates, see Figure $\mathrm{S} 22-\mathrm{S} 25)$. The resin (denoted as $\mathrm{Bz}-\mathrm{Az}_{2}+\mathrm{Al}-\mathrm{Ak}_{3}$ ) was composed of a molar ratio per functional group of $1: 1: 0.01: 0.02$ (azide from di-azide : alkyne from tri-alkyne : $\mathrm{CuCl}_{2}$ [PMDETA] : DMPA). The resins (denoted as $\mathrm{Bz}-\mathrm{Az}_{2}+\mathrm{Al}-\mathrm{Ak}_{3}+\mathrm{CB}-\mathrm{Ak}_{2}, \mathrm{Bz}-\mathrm{Az}_{2}+\mathrm{Al}-\mathrm{Ak}_{3}+5 \mathrm{C}-\mathrm{Ak}_{2}$, and $\mathrm{Bz}-\mathrm{Az} 2+\mathrm{Al}-\mathrm{Ak}_{3}+11 \mathrm{C}-\mathrm{Ak}_{2}$ ) were composed of a molar ratio per functional group of $1: 0.5: 0.5: 0.01: 0.02$ (azide from di-azide : alkyne from tri-alkyne : alkyne from di-alkyne : $\mathrm{CuCl}_{2}$ [PMDETA] : DMPA). Each mixture was irradiated

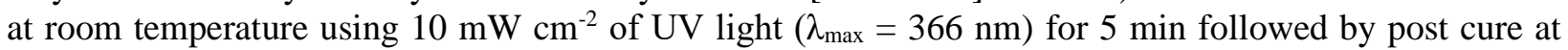
70-80 ${ }^{\circ} \mathrm{C}$ for $24-48$ hours. Each specimen was heated above $\mathrm{T}_{\mathrm{g}}$ for 1 minute followed by 3 minutes of cooling at ambient temperature prior to mechanical testing. 


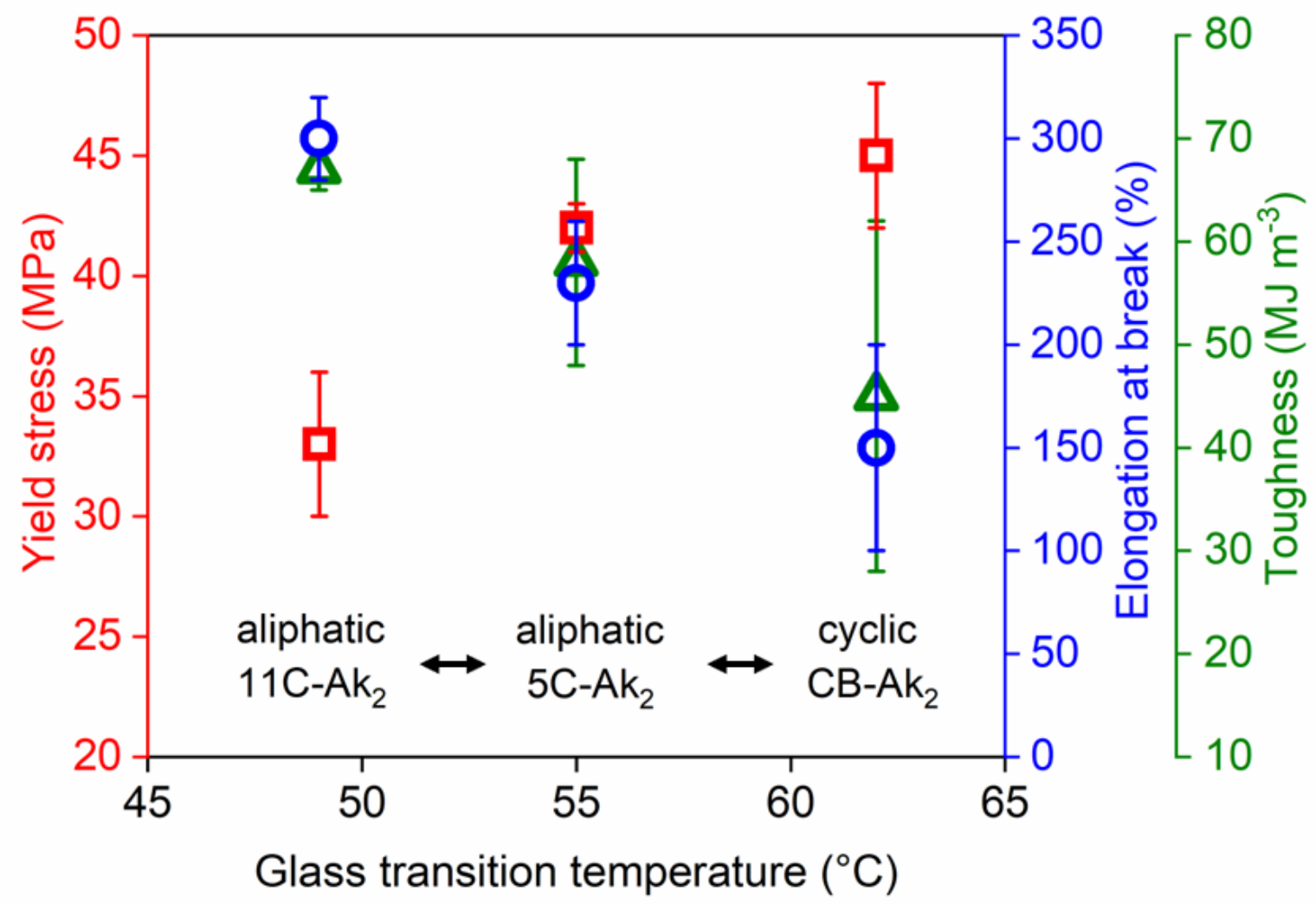

Figure S21. Correlation of $\mathrm{T}_{\mathrm{g}}$ and the tensile testing properties - yield stress (red squares), elongation to break (blue circles) and toughness (green triangles) - the three different networks, $\mathrm{Bz}-\mathrm{Az}_{2}+\mathrm{Al}-\mathrm{Ak}_{3}+\mathrm{CB}-$ $\mathrm{Ak}_{2}$ (denoted as cyclic CB-Ak $)_{2}, \mathrm{Bz}-\mathrm{Az}_{2}+\mathrm{Al}-\mathrm{Ak}_{3}+5 \mathrm{C}-\mathrm{Ak}_{2}$, (denoted as aliphatic $5 \mathrm{C}-\mathrm{Ak}_{2}$ ), and $\mathrm{Bz}-\mathrm{Az}_{2}$ $+\mathrm{Al}-\mathrm{Ak}_{3}+11 \mathrm{C}-\mathrm{Ak}_{2}$ (denoted as aliphatic $11 \mathrm{C}-\mathrm{Ak}_{2}$ ) whose structures are shown in Figure 2 were compared for the effect of backbone structure variations in their network with $\mathrm{Bz}-\mathrm{Az}_{2}$ and $\mathrm{Al}-\mathrm{Ak}_{3}$. A crosshead rate of $7.5 \mathrm{~mm} \mathrm{~min}^{-1}$ (a strain rate of $50 \% \mathrm{~min}^{-1}$ ) was utilized for tensile testing (see Figure S20 for the stress-strain curves). 


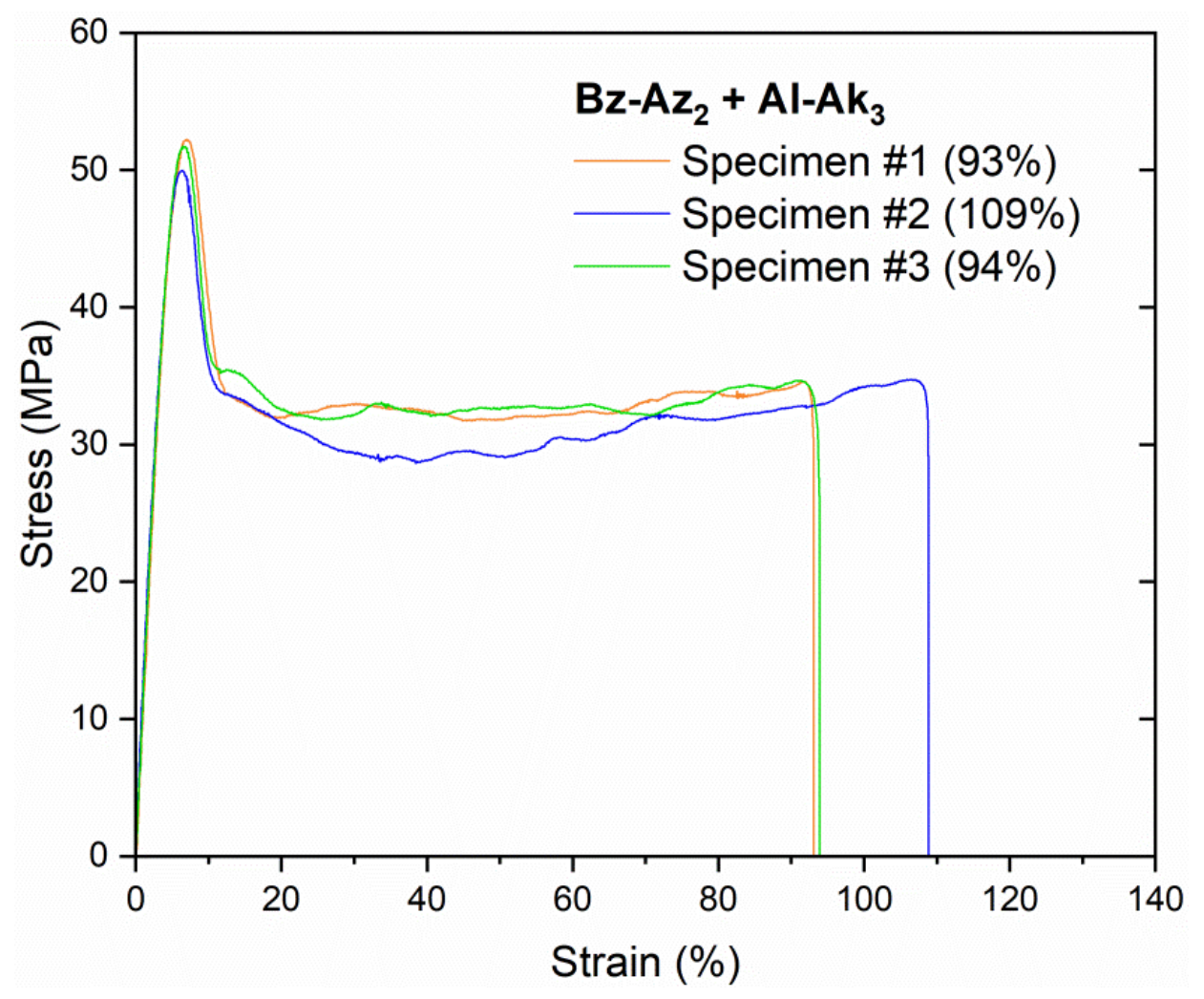

Figure S22. Tensile testing of the $\mathrm{Bz}-\mathrm{Az}_{2}+\mathrm{Al}-\mathrm{Ak}_{3}$ system in Figure $\mathrm{S} 20$ at a crosshead rate of $7.5 \mathrm{~mm}$ $\min ^{-1}$ (a strain rate of $50 \% \mathrm{~min}^{-1}$ ) using the MTS instrument. The resin was composed of a molar ratio per functional group of $1: 1: 0.01: 0.02$ (azide from di-azide : alkyne from tri-alkyne : $\mathrm{CuCl}_{2}$ [PMDETA] : DMPA). Each mixture was irradiated at room temperature using $10 \mathrm{~mW} \mathrm{~cm}^{-2}$ of UV light $\left(\lambda_{\max }=366 \mathrm{~nm}\right)$ for $5 \mathrm{~min}$ followed by post cure at $70-80{ }^{\circ} \mathrm{C}$ for $24-48$ hours. Each specimen was heated above $\mathrm{T}_{\mathrm{g}}$ for 1 minute followed by 3 minutes of cooling at ambient temperature prior to mechanical testing. 


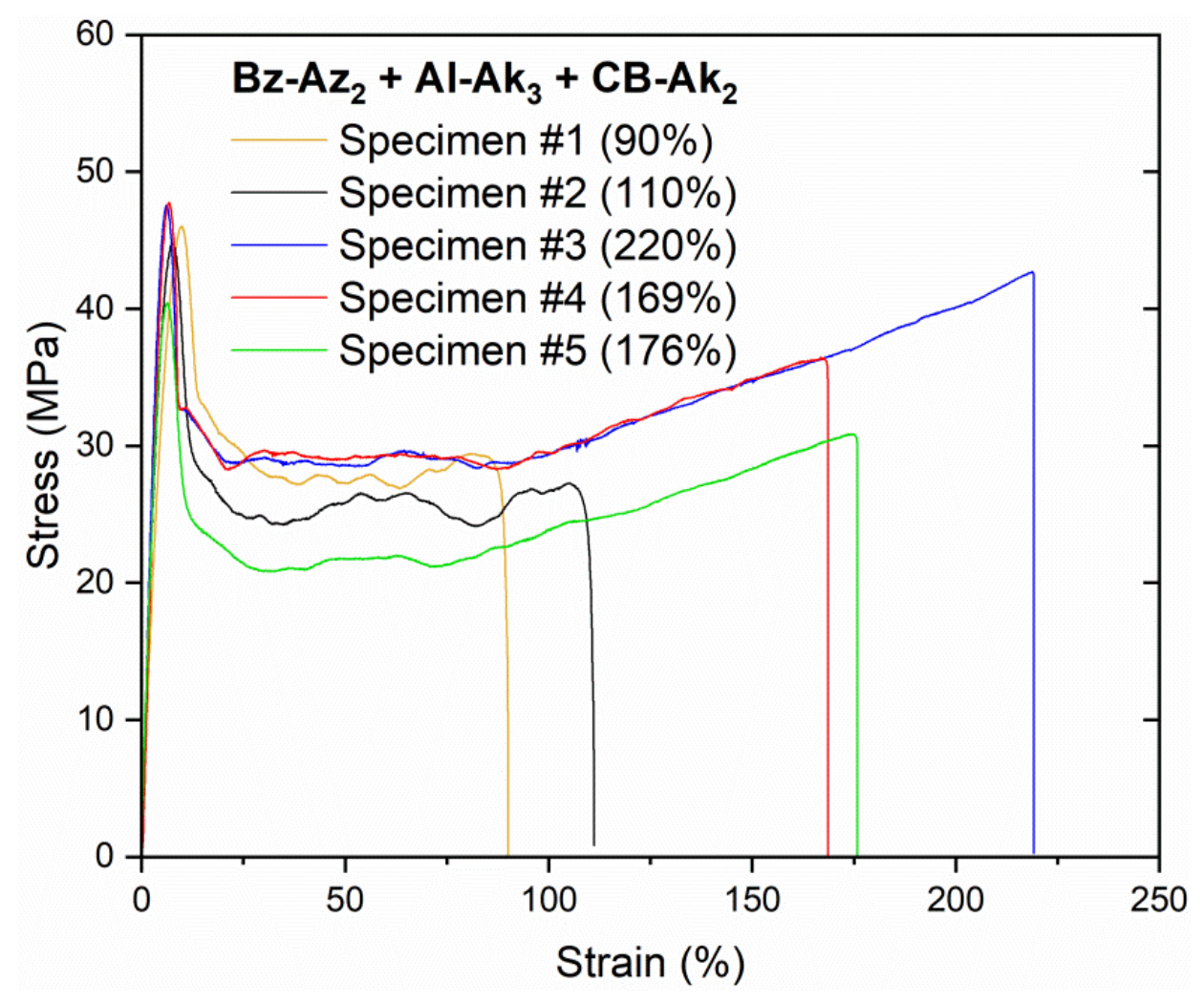

Figure S23. Tensile testing of the $\mathrm{Bz}_{-}-\mathrm{Az}_{2}+\mathrm{Al}-\mathrm{Ak}_{3}+\mathrm{CB}-\mathrm{Ak}_{2}$ system in Figure $\mathrm{S} 20$ at a crosshead rate of $7.5 \mathrm{~mm} \mathrm{~min}^{-1}$ (a strain rate of $50 \% \mathrm{~min}^{-1}$ ) using the MTS instrument. The resin was composed of a molar ratio per functional group of $1: 0.5: 0.5: 0.01: 0.02$ (azide from di-azide : alkyne from tri-alkyne : alkyne from di-alkyne : $\mathrm{CuCl}_{2}$ [PMDETA] : DMPA). Each mixture was irradiated at room temperature using $10 \mathrm{~mW} \mathrm{~cm}{ }^{-2}$ of UV light $\left(\lambda_{\max }=366 \mathrm{~nm}\right)$ for $5 \mathrm{~min}$ followed by post cure at $70-80{ }^{\circ} \mathrm{C}$ for $24-48$ hours. Each specimen was heated above $\mathrm{T}_{\mathrm{g}}$ for 1 minute followed by 3 minutes of cooling at ambient temperature prior to mechanical testing. 


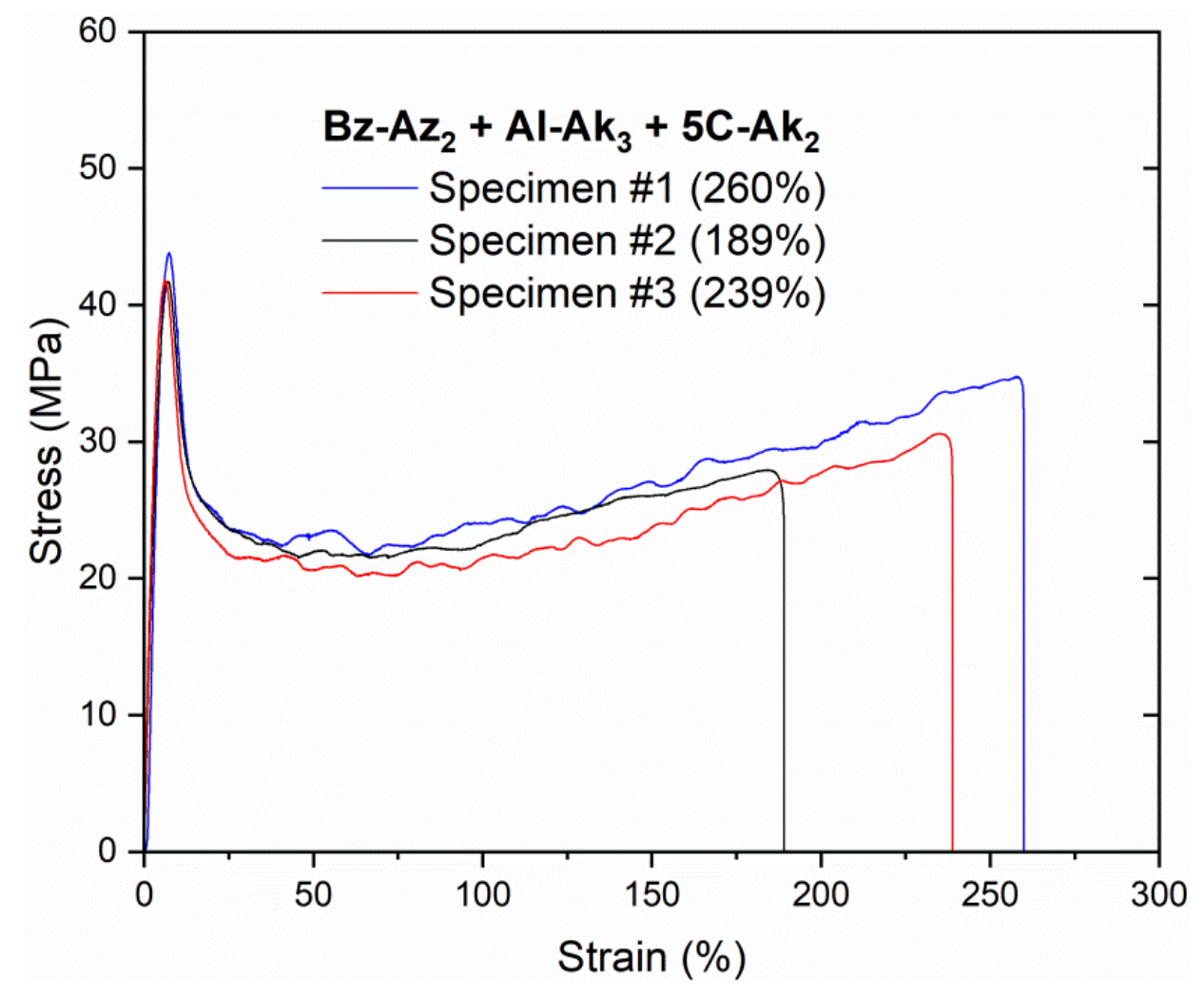

Figure S24. Tensile testing of the $\mathrm{Bz}-\mathrm{Az}_{2}+\mathrm{Al}-\mathrm{Ak}_{3}+5 \mathrm{C}-\mathrm{Ak}_{2}$ system in Figure $\mathrm{S} 20$ at a crosshead rate of $7.5 \mathrm{~mm} \mathrm{~min}^{-1}$ (a strain rate of $50 \% \mathrm{~min}^{-1}$ ) using the MTS instrument. The resin was composed of a molar ratio per functional group of $1: 0.5: 0.5: 0.01: 0.02$ (azide from di-azide : alkyne from tri-alkyne : alkyne from di-alkyne : $\mathrm{CuCl}_{2}$ [PMDETA] : DMPA). Each mixture was irradiated at room temperature using $10 \mathrm{~mW} \mathrm{~cm}{ }^{-2}$ of UV light $\left(\lambda_{\max }=366 \mathrm{~nm}\right)$ for 5 min followed by post cure at $70-80{ }^{\circ} \mathrm{C}$ for $24-48$ hours. Each specimen was heated above $\mathrm{T}_{\mathrm{g}}$ for 1 minute followed by 3 minutes of cooling at ambient temperature prior to mechanical testing. 


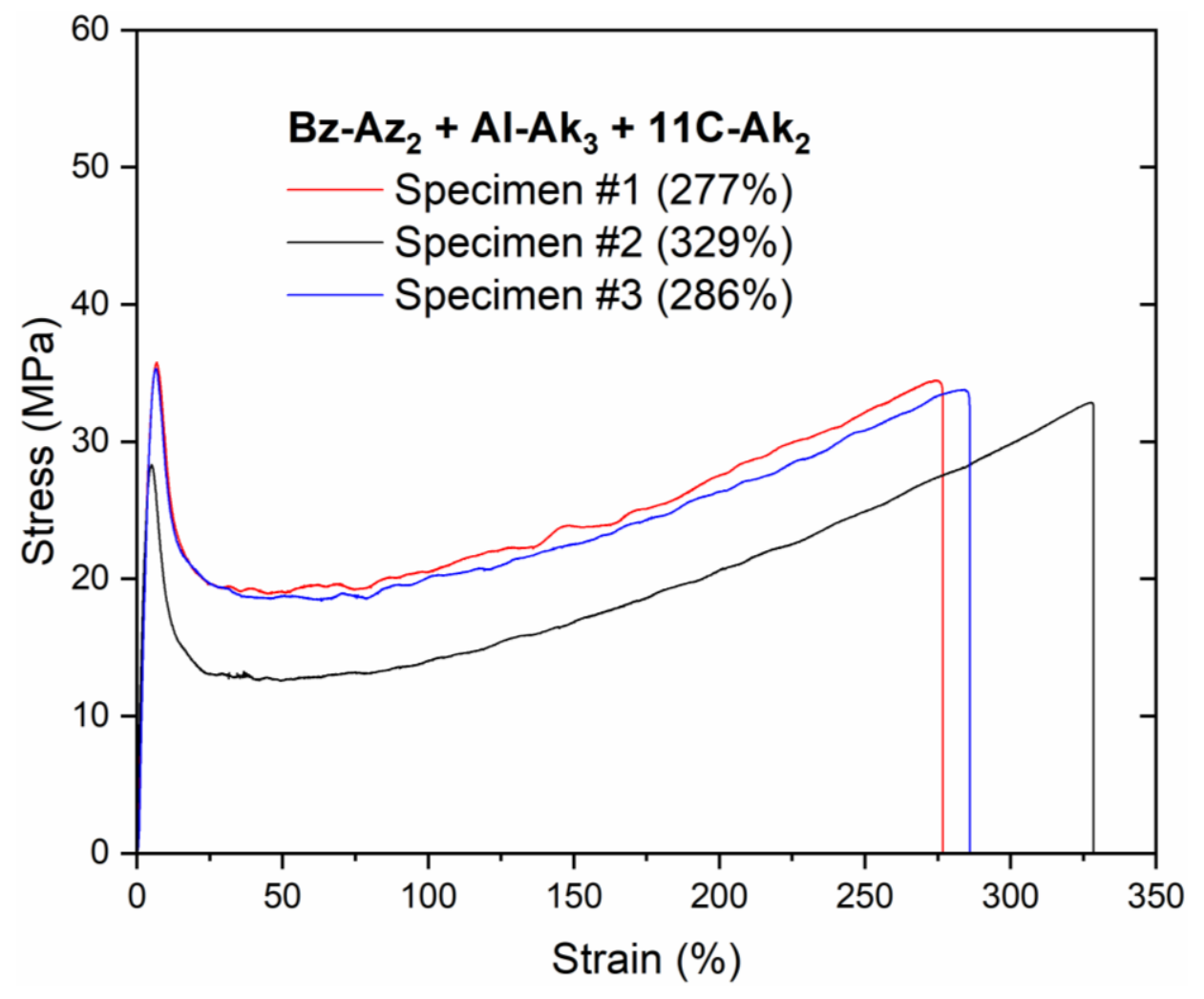

Figure S25. Tensile testing of the $\mathrm{Bz}-\mathrm{Az} \mathrm{z}_{2}+\mathrm{Al}-\mathrm{Ak}_{3}+11 \mathrm{C}-\mathrm{Ak}_{2}$ system in Figure $\mathrm{S} 20$ at a crosshead rate of $7.5 \mathrm{~mm} \mathrm{~min}^{-1}$ (a strain rate of $50 \% \mathrm{~min}^{-1}$ ) using the MTS instrument. The resin was composed of a molar ratio per functional group of $1: 0.5: 0.5: 0.01: 0.02$ (azide from di-azide : alkyne from tri-alkyne : alkyne from di-alkyne : $\mathrm{CuCl}_{2}$ [PMDETA] : DMPA). Each mixture was irradiated at room temperature using $10 \mathrm{~mW} \mathrm{~cm}{ }^{-2}$ of UV light $\left(\lambda_{\max }=366 \mathrm{~nm}\right)$ for 5 min followed by post cure at $70-80{ }^{\circ} \mathrm{C}$ for $24-48$ hours. Each specimen was heated above $\mathrm{T}_{\mathrm{g}}$ for 1 minute followed by 3 minutes of cooling at ambient temperature prior to mechanical testing. 

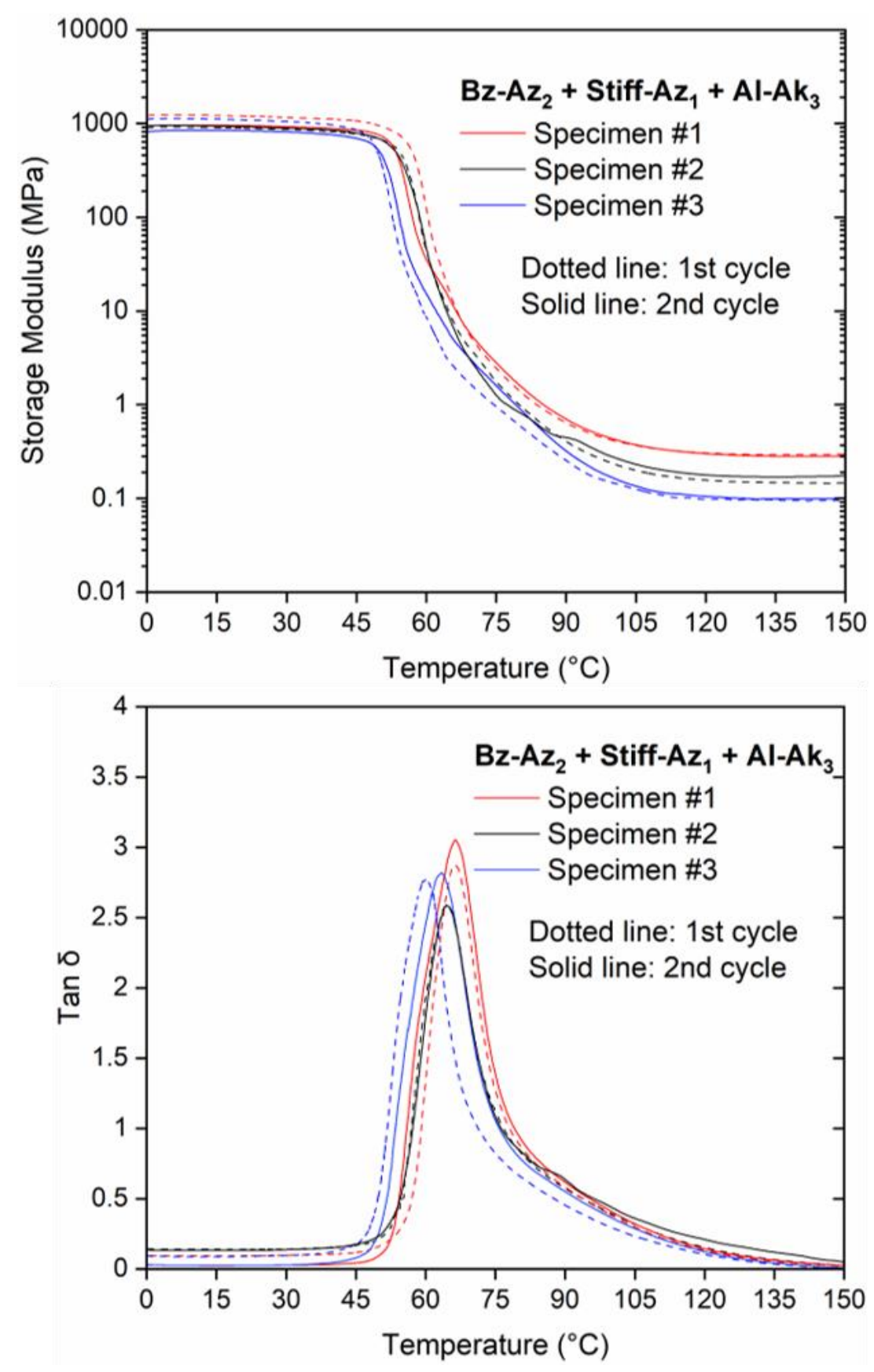

Figure S26. Thermo-mechanical properties of the $\mathrm{Bz}-\mathrm{Az}_{2}+\mathrm{Stiff}-\mathrm{Az}_{1}+\mathrm{Al}-\mathrm{Ak}_{3}$ system (structures shown in Figure 3) as measured by DMTA. The resin was composed of a molar ratio per functional group of $0.63: 0.37: 1: 0.01: 0.02$ (azide from di-azide : azide from mono-azide : alkyne from tri-alkyne : $\mathrm{CuCl}_{2}$ [PMDETA] : DMPA). Each mixture was irradiated at room temperature using $10 \mathrm{~mW} \mathrm{~cm} \mathrm{~cm}^{-2}$ of light $\left(\lambda_{\max }=366 \mathrm{~nm}\right)$ for $5 \mathrm{~min}$ followed by post cure at $70-80{ }^{\circ} \mathrm{C}$ for $24-48$ hours. The near overlap of the data for the first (dotted line) and second DMTA scans (solid line) indicates that nearly complete solvent removal and chemical cure was achieved after photopolymerization and the subsequent thermal post-cure. 

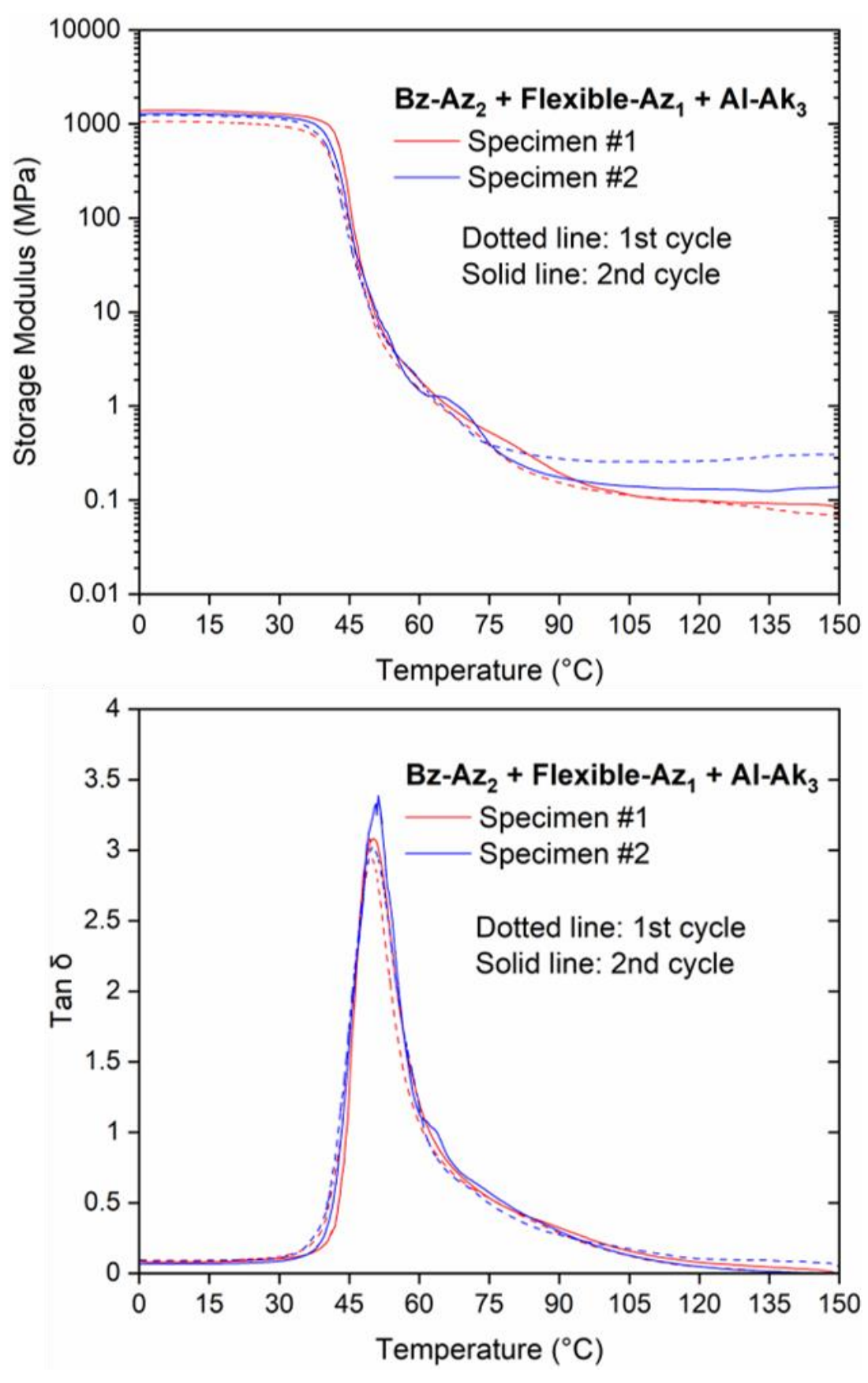

Figure S27. Thermo-mechanical properties of the $\mathrm{Bz}-\mathrm{Az}_{2}+$ Flexible- $\mathrm{Az}_{1}+\mathrm{Al}-\mathrm{Ak}_{3}$ system (structures shown in Figure 3) as measured by DMTA. The resin was composed of a molar ratio per functional group of $0.63: 0.37: 1: 0.01: 0.02$ (azide from di-azide : azide from mono-azide : alkyne from tri-alkyne : $\mathrm{CuCl}_{2}$ [PMDETA] : DMPA). Each mixture was irradiated at room temperature using $10 \mathrm{~mW} \mathrm{~cm}^{-2}$ of UV light $\left(\lambda_{\max }=366 \mathrm{~nm}\right)$ for $5 \mathrm{~min}$ followed by post cure at $70-80{ }^{\circ} \mathrm{C}$ for $24-48$ hours. The near overlap of the data for the first (dotted line) and second DMTA scans (solid line) indicates that nearly complete solvent removal and chemical cure was achieved after photopolymerization and the subsequent thermal post-cure. 
Table S3. A summary of tensile testing properties using a crosshead rate of $0.75 \mathrm{~mm} \mathrm{~min}^{-1}$ (a strain rate of $5 \% \mathrm{~min}^{-1}$ ) and DMTA mechanical behavior for the three different crosslinked systems from Figure 3. Errors listed for the tensile testing data are the SD obtained from multiple measurements $(\mathrm{n} \geq 5)$. Reported values for DMTA data are based on an average of at least two measurements for Bz-Az 2 Stiff-Az + Al$\mathrm{Ak}_{3}$ and $\mathrm{Bz}-\mathrm{Az}_{2}+$ Flexible-Az $+\mathrm{Al}-\mathrm{Ak}_{3}$, and a single measurement for $\mathrm{Bz}-\mathrm{Az} \mathrm{z}_{2}+\mathrm{Al}-\mathrm{Ak}_{3}$.

\begin{tabular}{|c|c|c|c|}
\hline & $\begin{array}{c}\mathrm{Bz}-\mathrm{Az}_{2}+ \\
\mathrm{Al}-\mathrm{Ak}_{3}\end{array}$ & $\begin{array}{c}\mathrm{Bz}-\mathrm{Az}_{2}+ \\
\text { Stiff-Az } \mathrm{z}_{1}+ \\
\mathrm{Al}-\mathrm{Ak}_{3}\end{array}$ & $\begin{array}{c}\mathrm{Bz}_{-} \mathrm{Az}_{2}+ \\
\text { Flexible-Az } \mathrm{z}_{1}+ \\
\mathrm{Al}-\mathrm{Ak}_{3}\end{array}$ \\
\hline $\mathrm{T}_{\mathrm{g}}$ from $\tan \delta$ maximum $\left({ }^{\circ} \mathrm{C}\right)$ & 62 & 64 & 50 \\
\hline Storage modulus@25 C C (GPa) & 1.1 & 1.0 & 1.2 \\
\hline Storage modulus@ $\mathrm{T}_{\mathrm{g}}+30^{\circ} \mathrm{C}(\mathrm{MPa})$ & 4.3 & 0.4 & 0.3 \\
\hline Network strand density, $v\left(\mathrm{mmol} \mathrm{g}^{-1}\right)$ & 0.47 & 0.04 & 0.03 \\
\hline Average molecular weight per strand, $\mathrm{M}_{\mathrm{c}}\left(\mathrm{g} \mathrm{mol}^{-1}\right)^{*}$ & 2100 & 23000 & 29000 \\
\hline Tensile yield stress $(\mathrm{MPa})$ & $39 \pm 3$ & $41 \pm 2$ & $23 \pm 3$ \\
\hline Tensile Young's modulus (MPa) & $1020 \pm 140$ & $1000 \pm 70$ & $820 \pm 110$ \\
\hline Tensile toughness $\left(\mathrm{MJ} \mathrm{m}^{-3}\right)$ & $45 \pm 8$ & $6 \pm 2$ & $28 \pm 2$ \\
\hline Tensile elongation at break (\%) & $140 \pm 20$ & $24 \pm 10$ & $185 \pm 14$ \\
\hline
\end{tabular}

* Calculated from the affine theory of rubber elasticity ${ }^{4}$ given by $\mathrm{E}=3 v \mathrm{dRT}$, where $\mathrm{E}$ is the rubbery modulus, $\mathrm{d}$ is the density of a sample (assumed to $1 \mathrm{~g} / \mathrm{cm}^{3}$ ), $\mathrm{R}$ is the gas constant, $\mathrm{T}$ is the temperature at rubbery plateau, $v$ is the network strand density and $M_{c}=1 / v$. 


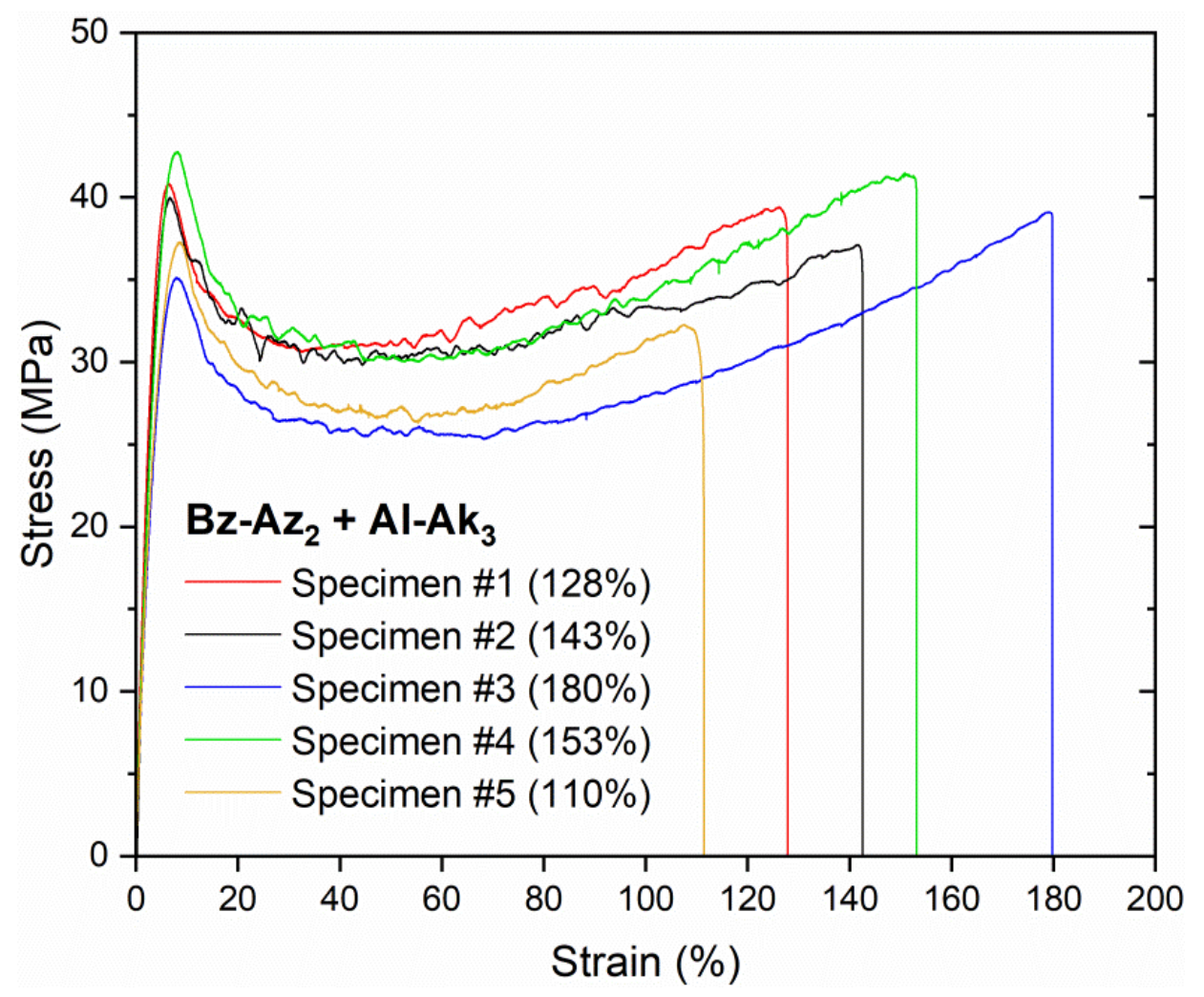

Figure S28. Tensile testing of the $\mathrm{Bz}_{-} \mathrm{Az}_{2}+\mathrm{Al}_{-} \mathrm{Ak}_{3}$ system in Figure 3 at a crosshead rate of $0.75 \mathrm{~mm}$ $\mathrm{min}^{-1}$ (a strain rate of $5 \% \mathrm{~min}^{-1}$ ) using the MTS instrument. The resin was composed of a molar ratio per functional group of $1: 1: 0.01: 0.02$ (azide from di-azide : alkyne from tri-alkyne : $\mathrm{CuCl}_{2}$ [PMDETA] : DMPA). Each mixture was irradiated at room temperature using $10 \mathrm{~mW} \mathrm{~cm}^{-2}$ of UV light $\left(\lambda_{\max }=366 \mathrm{~nm}\right)$ for $5 \mathrm{~min}$ followed by post cure at $70-80{ }^{\circ} \mathrm{C}$ for $24-48$ hours. Each specimen was heated above $\mathrm{T}_{\mathrm{g}}$ for 1 minute followed by 3 minutes of cooling at ambient temperature prior to mechanical testing. 


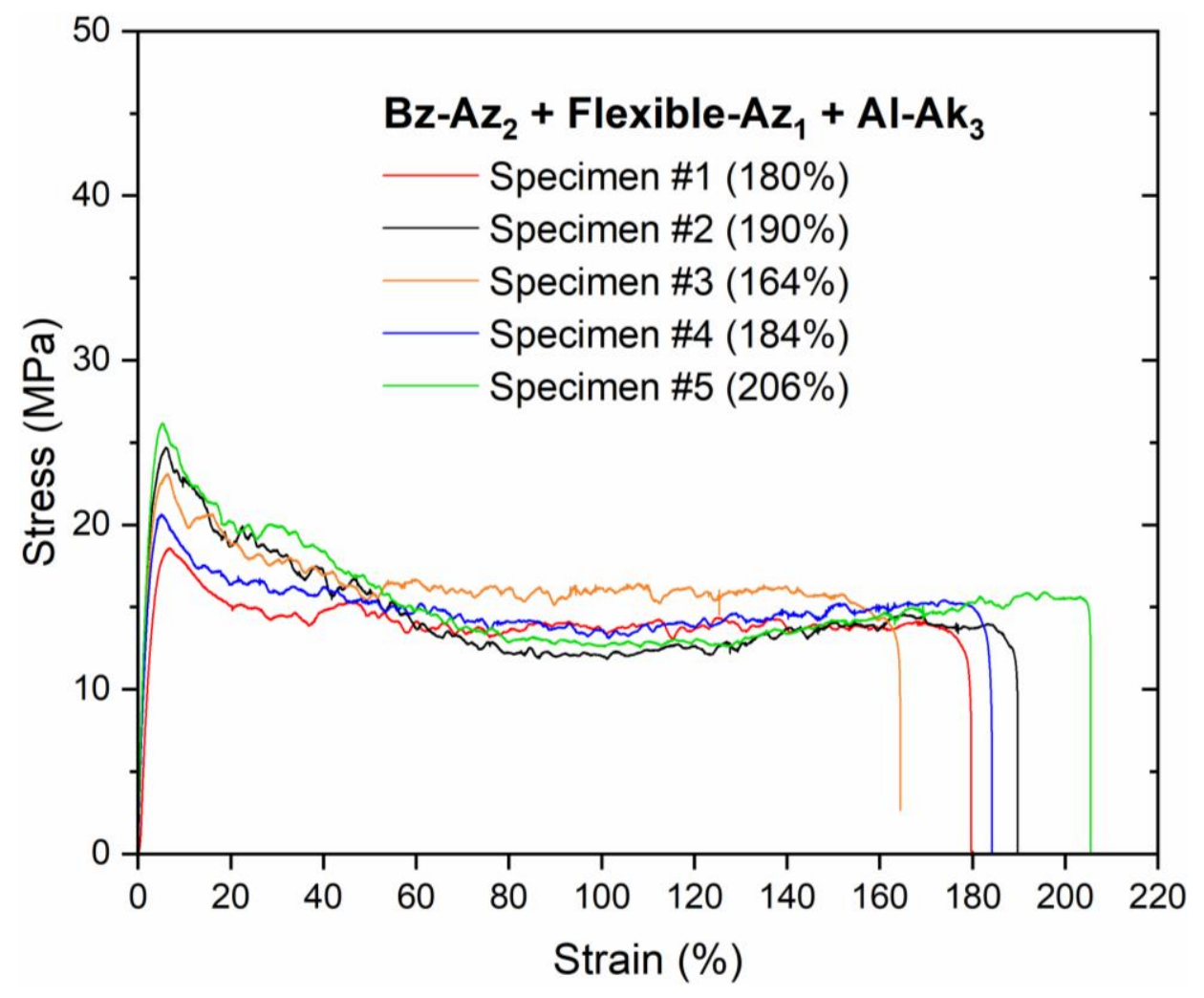

Figure S29. Tensile testing of the $\mathrm{Bz}-\mathrm{Az} \mathrm{z}_{2}+$ Flexible-Az $\mathrm{z}_{1}+\mathrm{Al}-\mathrm{Ak}_{3}$ system in Figure 3 at a crosshead rate of $0.75 \mathrm{~mm} \mathrm{~min}^{-1}$ (a strain rate of $5 \% \mathrm{~min}^{-1}$ ) using the MTS instrument. The resin was composed of a molar ratio per functional group of $0.63: 0.37: 1: 0.01: 0.02$ (azide from di-azide : azide from monoazide : alkyne from tri-alkyne : $\mathrm{CuCl}_{2}[\mathrm{PMDETA}]$ : DMPA). Each mixture was irradiated at room temperature using $10 \mathrm{~mW} \mathrm{~cm}^{-2}$ of UV light $\left(\lambda_{\max }=366 \mathrm{~nm}\right)$ for 5 min followed by post cure at $70-80{ }^{\circ} \mathrm{C}$ for 24-48 hours. Each specimen was heated above $T_{g}$ for 1 minute followed by 3 minutes of cooling at ambient temperature prior to mechanical testing. 


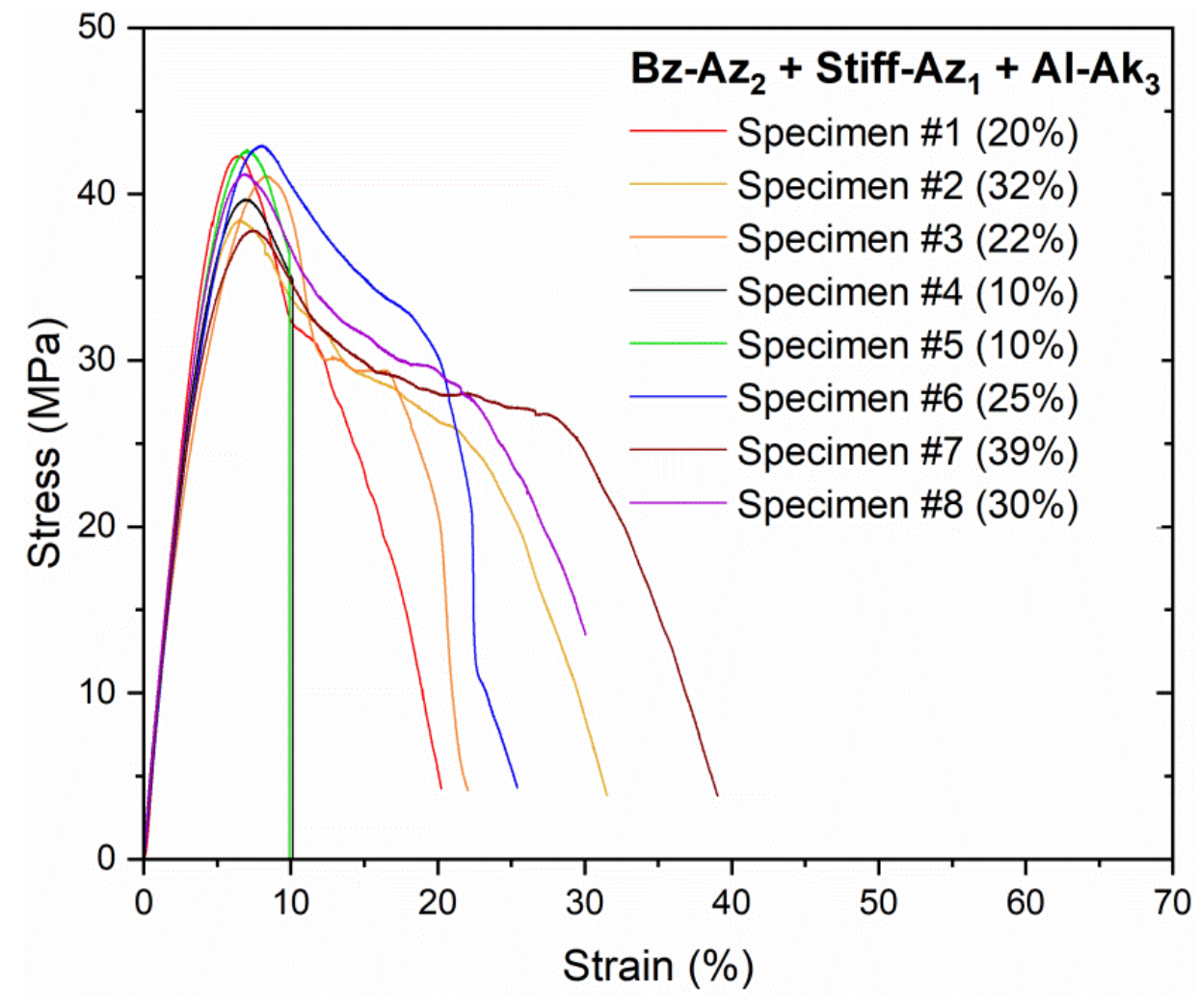

Figure S30. Tensile testing of the Bz-Az + Stiff-Az $1+A l-A k_{3}$ system in Figure 3 at a crosshead rate of $0.75 \mathrm{~mm} \mathrm{~min}^{-1}$ (a strain rate of $5 \% \mathrm{~min}^{-1}$ ) using the MTS instrument. The resin was composed of a molar ratio per functional group of $0.63: 0.37: 1: 0.01: 0.02$ (azide from di-azide : azide from mono-azide : alkyne from tri-alkyne : $\mathrm{CuCl}_{2}$ [PMDETA] : DMPA). Each mixture was irradiated at room temperature using $10 \mathrm{~mW} \mathrm{~cm}{ }^{-2}$ of UV light $\left(\lambda_{\max }=366 \mathrm{~nm}\right)$ for $5 \mathrm{~min}$ followed by post cure at $70-80{ }^{\circ} \mathrm{C}$ for $24-48$ hours. Each specimen was heated above $\mathrm{T}_{\mathrm{g}}$ for 1 minute followed by 3 minutes of cooling at ambient temperature prior to mechanical testing. 
Table S4. A summary of tensile testing properties using a crosshead rate of $0.75 \mathrm{~mm} \mathrm{~min}^{-1}$ (a strain rate of $5 \% \mathrm{~min}^{-1}$ ) and DMTA mechanical behavior for the three different crosslinked systems from Figure 3 at different concentrations of mono-azide monomers. Errors listed for the tensile testing data are the SD obtained from multiple measurements $(\mathrm{n}=7)$ for $\mathrm{Bz}-\mathrm{Az}_{2}+26 \mathrm{~mol} \%$ Stiff-Az $\mathrm{z}_{1}+\mathrm{Al}-\mathrm{Ak}_{3}$ and two measurements $(\mathrm{n}=2)$ for $\mathrm{Bz}-\mathrm{Az}_{2}+26 \mathrm{~mol} \%$ Flexible-Az $1+\mathrm{Al}-\mathrm{Ak}_{3}$. Reported values for DMTA data are based on an average of at least two measurements. It should be noted that mechanical data presented in Table S3 are repeated here for comparative purposes.

\begin{tabular}{|c|c|c|c|c|c|}
\hline & $\begin{array}{c}\mathrm{Bz}-\mathrm{Az}_{2}+ \\
\mathrm{Al}-\mathrm{Ak}_{3}\end{array}$ & $\begin{array}{r}\mathrm{Bz}-\mathrm{Az}_{2}+ \\
+\mathrm{A}\end{array}$ & $\begin{array}{l}A k_{3} \\
\text { tiff-Az }\end{array}$ & $\begin{array}{r}\mathrm{Bz}-\mathrm{Az}_{2}+ \\
+\mathrm{A}\end{array}$ & $\begin{array}{l}\text { xible- } A z_{1} \\
A k_{3}\end{array}$ \\
\hline Mole percentage of mono-azide (\%) & 0 & 26 & 37 & 26 & 37 \\
\hline $\mathrm{T}_{\mathrm{g}}$ from $\tan \delta$ maximum $\left({ }^{\circ} \mathrm{C}\right)$ & 62 & 65 & 64 & 59 & 50 \\
\hline Storage modulus @ $25^{\circ} \mathrm{C}(\mathrm{GPa})$ & 1.1 & 1.6 & 1.0 & 1.2 & 1.2 \\
\hline Storage modulus @ $\mathrm{T}_{\mathrm{g}}+30^{\circ} \mathrm{C}(\mathrm{MPa})$ & 4.3 & 2.1 & 0.4 & 1.8 & 0.3 \\
\hline Network strand density, $v\left(\mathrm{mmol} \mathrm{g}^{-1}\right)$ & 0.47 & 0.23 & 0.04 & 0.20 & 0.03 \\
\hline $\mathrm{M}_{\mathrm{c}}\left(\mathrm{g} \mathrm{mol}^{-1}\right)^{*}$ & 2100 & 4400 & 23000 & 5000 & 29000 \\
\hline Tensile yield stress (MPa) & $39 \pm 3$ & $42 \pm 6$ & $41 \pm 2$ & $36.0 \pm 0.4$ & $23 \pm 3$ \\
\hline Tensile Young's modulus (MPa) & $1020 \pm 140$ & $1130 \pm 200$ & $1000 \pm 70$ & $920 \pm 90$ & $820 \pm 110$ \\
\hline Tensile toughness $\left(\mathrm{MJ} \mathrm{m}^{-3}\right)$ & $45 \pm 8$ & $30 \pm 11$ & $6 \pm 2$ & $31 \pm 1$ & $28 \pm 2$ \\
\hline Tensile elongation at break (\%) & $140 \pm 20$ & $100 \pm 37$ & $24 \pm 10$ & $117 \pm 2$ & $185 \pm 14$ \\
\hline
\end{tabular}

${ }^{*} \mathrm{M}_{\mathrm{c}}$ refers to average molecular weight per strand calculated from the affine theory of rubber elasticity ${ }^{4}$ given by $\mathrm{E}=3 \mathrm{vdRT}$, where $\mathrm{E}$ is the rubbery modulus, $\mathrm{d}$ is the density of a sample (assumed to $1 \mathrm{~g} / \mathrm{cm}^{3}$ ), $\mathrm{R}$ is the gas constant, $\mathrm{T}$ is the temperature at rubbery plateau, $v$ is the network strand density and $\mathrm{M}_{\mathrm{c}}=1 / v$. 


\section{Gel point conversion}

The theoretical gel-point conversion in step-growth polymerizations is given by the FloryStockmayer equation: ${ }^{5-11} p_{g e l}=\frac{1}{r\left\{\left(f_{w, A}-1\right)\left(f_{w, B}-1\right)\right\}^{0.5}}$ where $p_{g e l}$ is the gel point conversion, $r$ is the stoichiometric ratio of the two reactive functional groups, and $f_{w, A}$ and $f_{w, B}$ are the molarweighted average functionalities of the two monomer type A and B (in this case, azide and alkyne). The molar-weighted average functionalities of and $f_{w, A}$ and $f_{w, B}$ are defined by $f_{w, A}=$ $\frac{\sum f_{A_{i}}^{2} N_{A_{i}}}{\sum f_{A_{i}} N_{A_{i}}}$ and $f_{w, B}=\frac{\sum f_{B_{j}}^{2} N_{B_{j}}}{\sum f_{B_{j}} N_{B_{j}}}$ where $\mathrm{A}$ and $\mathrm{B}$ are the type of reactive functional groups, $N_{A_{i}}$ and $N_{B_{i}}$ are the number of moles of $A_{i}$ and $B_{i}$ monomers, and $f_{A_{i}}$ and $f_{B_{i}}$ are the number of functional groups per molecule of $A_{i}$ and $B_{i}$ monomers. This summation is accounted for all monomers of A and $\mathrm{B}$ types ranging from mono- to $\mathrm{i}$-th functional groups for A type monomer and mono- to $\mathrm{j}$-th functional groups for B type monomer. Thus, the theoretical gel-point conversions were calculated to be $58 \%$ for the di-azide + tetra-alkyne polymer, $71 \%$ for the di-azide + tri-alkyne polymers, $82 \%$ for the di-azide + tri-alkyne + di-alkyne polymers, and $89 \%$ for the di-azide + mono-azide + tri-alkyne polymers. 


\section{Reference}

(1) Gong, T.; Adzima, B. J.; Baker, N. H.; Bowman, C. N. Photopolymerization Reactions Using the Photoinitiated Copper (I)-Catalyzed Azide-Alkyne Cycloaddition (CuAAC) Reaction. Adv. Mater. 2013, 25 (14), 2024-2028.

(2) Baranek, A.; Song, H. B.; McBride, M.; Finnegan, P.; Bowman, C. N. Thermomechanical Formation-Structure-Property Relationships in Photopolymerized Copper-Catalyzed Azide-Alkyne (CuAAC) Networks. Macromolecules 2016, 49 (4), 1191-1200.

(3) Song, H. B.; Baranek, A.; Bowman, C. N. Kinetics of Bulk Photo-Initiated Copper(I)Catalyzed Azide-Alkyne Cycloaddition (CuAAC) Polymerizations. Polym. Chem. 2016, 7 (3), 603-612.

(4) Flory, P. J. Principles of Polymer Chemistry; Cornell University Press, 1953.

(5) Stockmayer, W. H. Molecular Distribution in Condensation Polymers. J. Polym. Sci. 1952, $9(1), 69-71$.

(6) Flory, P. J. Molecular Size Distribution in Three Dimensional Polymers. I. Gelation. J. Am. Chem. Soc. 1941, 63 (11), 3083-3090.

(7) Flory, P. J. Molecular Size Distribution in Three Dimensional Polymers. II. Trifunctional Branching Units. J. Am. Chem. Soc. 1941, 63 (11), 3091-3096.

(8) Flory, P. J. Fundamental Principles of Condensation Polymerization. Chem. Rev. 1946, 39 (1), 137-197.

(9) Flory, P. J. Molecular Size Distribution in Three Dimensional Polymers. V. Post-Gelation Relationships. J. Am. Chem. Soc. 1947, 69 (1), 30-35.

(10) Miller, D. R.; Macosko, C. W. A New Derivation of Post Gel Properties of Network Polymers. Macromolecules 1976, 9 (2), 206-211.

(11) Odian, G. Principles of Polymerization; Wiley-Interscience, 2004. 